\title{
Conformation analysis of triphenylphosphine in trans and cis triphenylphosphine-substituted Fischer carbene complexes
}

Marilé Landman, ${ }^{[\mathrm{a}] *}$ Tamzyn Levell, ${ }^{[\mathrm{a}]}$ Petrus H van Rooyen ${ }^{[\mathrm{a}]}$ and Jeanet Conradie ${ }^{[\mathrm{b}] *}$

a Department of Chemistry, University of Pretoria, Private Bag X20, Hatfield, 0028, South Africa, Fax: +27 124204687

b Department of Chemistry, University of the Free State, P.O. Box 339, Bloemfontein, 9300, Republic of South Africa, Fax: +27 51-444 6384

*Contact author details:

Marilé Landman

Tel: +27-12-4202527

Fax: +27 12-420 4687

E-mail: marile.landman@up.ac.za

or

Name: Jeanet Conradie

Tel: +27-51-4012194

Fax: +27-51-4446384

E-mail: conradj@ufs.ac.za

\section{Graphical abstract}

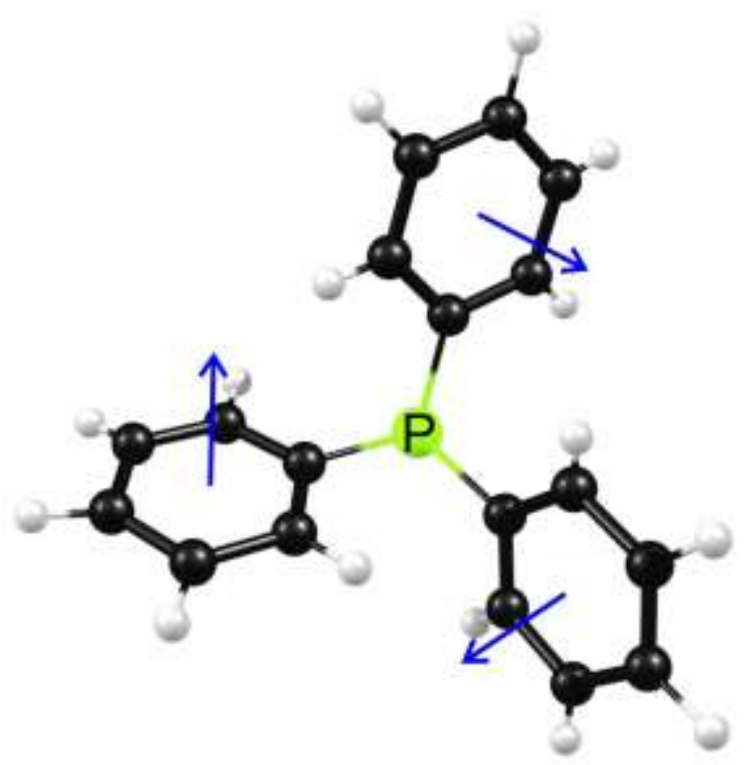

TOC abstract

Orientation of triphenylphosphine in octahedral $\left[(\mathrm{CO})_{4}\left(\mathrm{PPh}_{3}\right) \mathrm{W}\right.$-carbene] complexes. 


\title{
Highlights
}

Synthesis of novel $\left[(\mathrm{CO})_{4}\left(\mathrm{PPh}_{3}\right) \mathrm{M}(\mathrm{OEt})(\operatorname{aryl})\right.$-carbene $]$ complexes, $\mathrm{M}=\mathrm{Cr}$ or $\mathrm{Mo}$

First crystal structure of a trans-[(CO $)_{4}\left(\mathrm{PPh}_{3}\right) \mathrm{M}$-carbene], $\mathrm{M}=\mathrm{W}$

Crystal structures of cis-[(CO) $)_{4}\left(\mathrm{PPh}_{3}\right) \mathrm{M}$-carbene] complexes

$\mathrm{PPh}_{3}$ orientation in octahedral trans- and cis-[(CO) $)_{4}\left(\mathrm{PPh}_{3}\right) \mathrm{M}$-carbene $]$ complexes

Remarkable performance of DFT to determine $\mathrm{PPh}_{3}$ orientation

\begin{abstract}
The synthesis and selected crystal structures of novel $(\mathrm{M}=\mathrm{Cr}$ or Mo) and known $(\mathrm{M}=\mathrm{W})$ $\left[(\mathrm{CO})_{4}\left(\mathrm{PPh}_{3}\right) \mathrm{M}=\mathrm{C}(\mathrm{OEt}) \mathrm{R}\right]$ complexes, $\mathrm{M}=\mathrm{Cr}, \mathrm{R}=2$-thienyl (1), 2-furyl (2); $\mathrm{M}=\mathrm{Mo}, \mathrm{R}=2$ thienyl (3), 2-furyl (4); M = W, R = 2-thienyl (5), 2-furyl (6), are presented. Experimental crystal structures and DFT calculations of selected trans- and cis- triphenylphosphinesubstituted Fischer carbene complexes, illustrate that the minimum energy conformation of triphenylphosphine $\left(\mathrm{PPh}_{3}\right)$ in octahedral $\left[(\mathrm{CO})_{4}\left(\mathrm{PPh}_{3}\right) \mathrm{ML}\right]$-complexes generally have distinct features that can be described in terms of the "plane of nadir energy", a plane linking all points of minimum steric compression between the ligands. The generally observed orientation of $\mathrm{PPh}_{3}$ involves a correlated feathering of the phenyl groups with the $\mathrm{P}-\mathrm{C}_{i p s o}$ bond of one phenyl group orientated near parallel to the nadir plane, and a meta carbon $\left(\mathrm{C}_{m}\right)$ of the other two phenyl groups orientated as near as possible to the nadir plane, orthogonal to the first. Although the orientation of $\mathrm{PPh}_{3}$ in 6-trans, $\left[(\mathrm{CO})_{4}\left(\mathrm{PPh}_{3}\right) \mathrm{W}=\mathrm{C}(\mathrm{OEt}) 2\right.$-furyl], deviates from this, DFT correctly calculated the unexpected and not generally observed $\mathrm{PPh}_{3}$ orientation.
\end{abstract}

\section{Keywords}

Fischer carbene; Phosphine; DFT; Conformational analysis

\section{Introduction}

The electronic structure of the metal-carbon bond in carbene complexes determines the reactivity of the complex [1]. Fischer carbene complexes feature strong $\pi$-acceptors ligands at the metal centre and are electrophilic at the carbene carbon atom [2]. Modification of the ligand sphere around the metal centre will alter the electronic properties of the complex and hence its reactivity. One of the applications of the Fischer carbenes is in the field of catalysis [3]. Fischer carbene complexes are known to transfer $\mathrm{CR}_{2}$ moieties $(\mathrm{R}=\mathrm{H}$, alkyl, aryl, alkoxy, amino) in cyclopropanation and olefin metathesis reactions [4]. However, because 
they are coordinately and electronically saturated, these complexes do not normally initiate olefin metathesis. Only under thermal or photochemical activation, or in the presence of a cocatalyst can they can initiate a metathesis reaction.

Phosphines have many applications in organometallic chemistry, specifically as ligands in homogenous catalysts [5]. Combining phosphines and carbenes in one complex may lead to synergy regarding the catalytic properties, as was the result for reactions with electrophiles [6] and photocarbonylation reactions [7]. In phosphine-substituted Fischer carbene complexes, the phosphine group is often the most bulky part of the molecule. In the case of triphenylphosphine-containing complexes, the conformation of the phenyl rings often contributes to the bulkiness of the complex. The most bulky part of the molecule frequently determines the shape and reactivity of the complex [8]. Therefore, knowledge of the preferred conformation of the phenyl rings in triphenylphosphine-containing complexes could provide important information to the development of catalysts, especially in stereoselective reactions.

This contribution presents the synthesis and characterization of novel $(\mathrm{M}=\mathrm{Cr}$ or $\mathrm{Mo})$ and known $(\mathrm{M}=\mathrm{W})\left[(\mathrm{CO})_{4}\left(\mathrm{PPh}_{3}\right) \mathrm{M}=\mathrm{C}(\mathrm{OEt}) \mathrm{R}\right]$ complexes, $\mathrm{M}=\mathrm{Cr}, \mathrm{R}=2$-thienyl (1), 2-furyl (2); $\mathrm{M}=\mathrm{Mo}, \mathrm{R}=$ 2-thienyl (3), 2-furyl (4); $\mathrm{M}=\mathrm{W}, \mathrm{R}=$ 2-thienyl (5), 2-furyl (6), focusing on the structure of three selected triphenylphosphine-substituted Fischer carbene complexes (1-cis, 4-cis and 6-trans) and the preferred orientation of triphenylphosphine in the complexes. In this study, we report the first structure of a trans-substituted phosphine carbene complex (6trans).

\section{Experimental}

\section{General}

All reactions, unless otherwise noted, were performed under inert nitrogen or argon atmospheres using standard Schlenk techniques. All solvents were freshly distilled, dried, and collected under inert conditions, with the exception of toluene. Toluene was not dried but was used after nitrogen gas was bubbled through the solvent for 5-10 min. All other reagents were used directly. Column chromatography was carried out under inert nitrogen and argon atmospheres at $-10^{\circ} \mathrm{C}$ using silica gel (particle size $0.063-0.200 \mathrm{~mm}$ ) as the stationary phase. All percentage yields were calculated relative to the limiting reactant. All crystallizations were done using hexane/DCM diffusion methods. The reagents $\mathrm{Cr}(\mathrm{CO})_{6}, \mathrm{Mo}(\mathrm{CO})_{6}, \mathrm{~W}(\mathrm{CO})_{6}$, 
butyllithium (1.6 M solution in hexane), furan, $\mathrm{PPh}_{3}$ and other commercial reagents were used as purchased. NMR spectra were recorded on a Bruker ARX-300, Bruker Ultra Shield 400 Plus AVANCE III, and Bruker AVANCE 500 instruments. NMR spectra were recorded in $\mathrm{CDCl}_{3}, \mathrm{CD}_{2} \mathrm{Cl}_{2}$, or $\mathrm{CD}_{3} \mathrm{CN}$ using deuterated solvent peaks as the internal references. IR spectra were recorded on a Perkin-Elmer Spectrum RXI FT-IR spectrophotometer. All spectra were recorded as $\mathrm{KBr}$ pellets, and only the vibration bands in the carbonyl stretching region (ca. 1500-2200 $\mathrm{cm}^{-1}$ ) are reported. Mass spectra were recorded on a SYNAPT G2 HDMS instrument with the TOF-MS method with a sampling time of $4 \mathrm{~min}$., by the direct infusion inlet method. The source was electron spray ionization. Commercial thiophene was purified [9] and triethyloxonium tetrafluoroborate [10], [(CO) ${ }_{5} \mathrm{Cr}=\mathrm{C}(\mathrm{OEt}) 2$-thienyl] (I) [11], $\left[(\mathrm{CO})_{5} \mathrm{Cr}=\mathrm{C}(\mathrm{OEt}) 2\right.$-furyl $] \quad$ (II) $\quad[11],[12], \quad\left[(\mathrm{CO})_{5} \mathrm{Mo}=\mathrm{C}(\mathrm{OEt}) 2\right.$-thienyl $] \quad$ (III), [13] $\left[(\mathrm{CO})_{5} \mathrm{~W}=\mathrm{C}(\mathrm{OEt}) 2\right.$-thienyl $] \quad(\mathbf{V}) \quad[14], \quad\left[(\mathrm{CO})_{5} \mathrm{~W}=\mathrm{C}(\mathrm{OEt}) 2\right.$-furyl $] \quad(\mathbf{V I}) \quad[12]$, $\left[(\mathrm{CO})_{4}\left(\mathrm{PPh}_{3}\right) \mathrm{W}=\mathrm{C}(\mathrm{OEt}) 2 \text {-thienyl] (5) [15] and [(CO) }\right)_{4}\left(\mathrm{PPh}_{3}\right) \mathrm{W}=\mathrm{C}(\mathrm{OEt}) 2$-furyl $](6)$ [15] were prepared according to reported literature procedures. The synthesis and characterization data of 1-6, as well as that of the novel precursor [(CO) ${ }_{5} \mathrm{Mo}=\mathrm{C}(\mathrm{OEt}) 2$-furyl], $(\mathbf{I V})$, of complex 4, are reported below. The carbon atoms for NMR were assigned according to the numbering of scheme 1.

\section{Synthesis}

Synthesis of $\left[(\mathrm{CO})_{5} \mathrm{Mo}=\mathrm{C}(\mathrm{OEt}) 2\right.$-furyl $]$, complex $\mathbf{I V}$

Furan $(0.32 \mathrm{~mL}, 4.37 \mathrm{mmol})$ in $15 \mathrm{~mL}$ THF was cooled to $-35{ }^{\circ} \mathrm{C}$, and ${ }^{\mathrm{n}} \mathrm{BuLi}(1.5 \mathrm{M}, 3.13$ $\mathrm{mL}, 4.70 \mathrm{mmol}$ ) was added dropwise, resulting in a pale yellow solution. The reaction was allowed to stir at $-35{ }^{\circ} \mathrm{C}$ for $40 \mathrm{~min}$. $\mathrm{Mo}(\mathrm{CO})_{6}(1.320 \mathrm{~g}, 4.99 \mathrm{mmol})$ was added and the reaction allowed to stir cold for a further $20 \mathrm{~min}$ (bright yellow solution), and then at RT for $1 \mathrm{hr}$ (dark red brown solution). The solvent was then removed, and a dark brown oil obtained. This product was dissolved in $30 \mathrm{~mL}$ of dichloromethane (DCM) and cooled to -40 ${ }^{\circ} \mathrm{C} \mathrm{Et}_{3} \mathrm{OBF}_{4}$ in $\mathrm{DCM}(0.2454 \mathrm{~g} / \mathrm{mL}, 5 \mathrm{~mL}, 6.46 \mathrm{mmol})$ was added to the reaction mixture and allowed to stir for $30 \mathrm{~min}$. The reaction was then allowed to stir at RT for $1 \mathrm{hr}$, yielding a dark red-brown solution which was filtered through silica gel and rinsed off with DCM. A dark red-brown solid was obtained after solvent removal. The product was purified on silica gel with a hexane:DCM mixture (1:1).

[(CO) $)_{5} \mathrm{Mo}=\mathrm{C}(\mathrm{OEt}) 2$-furyl], $(\mathbf{I V})$ : Yield $39.9 \%$, red solid. ${ }^{1} \mathrm{H} \mathrm{NMR}\left(\mathrm{CDCl}_{3}, \mathrm{ppm}\right): 7.83$ (dd, H10, 1.7, 0.8 Hz), $\delta 7.09$ (dd, H8, 3.6, 0.8 Hz), 6.58 (dd, H9, 3.7, 1.7 Hz), 5.03 (q, H1 1, 7.1 
$\mathrm{Hz}), 1.62(\mathrm{t}, \mathrm{H} 12,7.0 \mathrm{~Hz}) .{ }^{13} \mathrm{C} \mathrm{NMR}\left(\mathrm{CDCl}_{3}, \mathrm{ppm}\right): \delta 301.1(\mathrm{C} 6), 213.5\left(\mathrm{~s}, \mathrm{CO}_{\text {trans }}\right), 206.0(\mathrm{t}$, $\mathrm{CO}_{\text {cis }}$ ), 164.4 (C7), 150.0 (C10), 114.6 (C8), 113.2 (C9), 76.6 (C11), 15.2 (C12). IR (KBr, $\left.\mathrm{cm}^{-1}\right): v_{\mathrm{CO}} 2068(\mathrm{~m}), 1988(\mathrm{~m}) 1942(\mathrm{~s}) 1923$ (vs).

\section{Synthesis of complexes 1-6}

The relevant monocarbene complex I-VI $(3.00 \mathrm{mmol})$ and $\mathrm{PPh}_{3}(0.945 \mathrm{~g}, 3.60 \mathrm{mmol})$ were dissolved in $30 \mathrm{ml}$ of toluene (red solution). This mixture was left to reflux for 8 hours. The solvent was removed from the resulting dark brown solution to yield a dark brown residue. The crude product was purified on a silica gel column, cooled to $-10^{\circ} \mathrm{C}$, using varying hexane:dichloromethane gradients. Unreacted monocarbene I-VI and two products were observed on TLC (thin layer chromatography). The two products were identified as the slightly less polar trans product, a yellow-brown colour, and the cis product, a red-brown colour. For 1-4, only the cis product was isolated after column chromatography, as the trans product isomerized or decomposed on the column. For complexes 5 and 6 [15], both the isomers could be isolated and characterized.

1-cis: Yield 62.4\%, brown solid. ${ }^{1} \mathrm{H}$ NMR $\left(\mathrm{C}_{6} \mathrm{D}_{6}, \mathrm{ppm}\right): \delta 7.45$ (s, br, H8), 6.79 (s, br, H10), 6.54 (s, br, H9), 4.03 (q, H11, 7.3 Hz), 0.94 (t, H12, 7.1 Hz), 6.92-7.46 (m, PPh 3 ). ${ }^{13} \mathrm{C} \mathrm{NMR}$ $\left(\mathrm{CDCl}_{3}, \mathrm{ppm}\right): \delta 234.0$ (CO1), 222.3 (CO3), 217.8 (CO2), 162.3 (C7), 135.2 (C10), 136.3 (C8), 131.9 (C9), 61.3 (C11), 14.6 (C12), 134.7, 132.4, 130.7, 129.1 (PPh $)_{3}{ }^{31} \mathrm{P}$ NMR $\left(\mathrm{C}_{6} \mathrm{D}_{6}\right.$, ppm): $\delta 25.16$. IR (KBr, cm $\left.{ }^{-1}\right): v_{\mathrm{CO}} 2004(\mathrm{w}), 1940(\mathrm{~m}), 1889$ (vs).

2-cis: Yield 54.2\%, brown solid. ${ }^{1} \mathrm{H}$ NMR $\left(\mathrm{C}_{6} \mathrm{D}_{6}, \mathrm{ppm}\right): \delta 7.60$ (s, br, H10), 6.66 (s, br, H8),

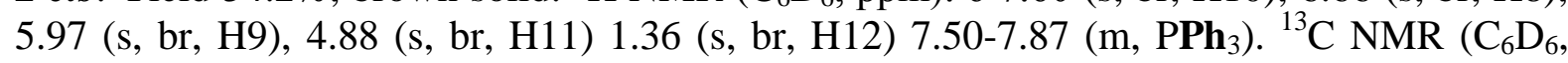
ppm): $\delta 315.2$ (C6), 228.0 (CO1), 222.6 (CO3), 217.8 (CO2), 164.9 (C7), 130.7 (C10), 112.6 (C8), 110.2 (C9), 75.1 (C11), 14.7 (C12), 134.6, 132.8, $129.2\left(\mathrm{PPh}_{3}\right) .{ }^{31} \mathrm{P}$ NMR $\left(\mathrm{C}_{6} \mathrm{D}_{6}, \mathrm{ppm}\right)$ : $\delta$ 25.09. IR (KBr, cm $\left.{ }^{-1}\right): v_{\mathrm{CO}} 2004(\mathrm{w}), 1932(\mathrm{~m}), 1921(\mathrm{~m}), 1879(\mathrm{vs})$.

3-cis: Yield 56.3\%, brown solid. ${ }^{1} \mathrm{H}$ NMR $\left(\mathrm{C}_{6} \mathrm{D}_{6}, \mathrm{ppm}\right): \delta 7.12(\mathrm{~d}, \mathrm{H} 8,7.6 \mathrm{~Hz}), 6.84(\mathrm{~d}, \mathrm{H} 10$, $4.8 \mathrm{~Hz}$ ), 6.57 (dd, H9, 4.9, 3.9 Hz), 4.06 (q, H11, 7.1 Hz), 0.98 (t, H12, 7.1 Hz), 7.42-7.72 (m, PPh $\left.{ }_{3}\right) .{ }^{13} \mathrm{C} \mathrm{NMR}\left(\mathrm{C}_{6} \mathrm{D}_{6}, \mathrm{ppm}\right): 212.6$ (CO1), 210.7 (CO3), 206.7 (CO2), 136.5 (C10), 136.0 (C9), 135.2 (C8), 162.3 (C7), 61.3 (C11), 12.0 (C12), 133.4, 133.5, $133.6\left(\mathrm{PPh}_{3}\right) .{ }^{31} \mathrm{P}$ NMR $\left(\mathrm{C}_{6} \mathrm{D}_{6}, \mathrm{ppm}\right): \delta 37.83 . \mathrm{IR}\left(\mathrm{KBr}, \mathrm{cm}^{-1}\right)$ : $\mathrm{v}_{\mathrm{CO}} 1994(\mathrm{w}), 1923(\mathrm{~m}), 1889$ (vs).

4-cis: Yield 40.6\%, brown solid. ${ }^{1} \mathrm{H}$ NMR $\left(\mathrm{CD}_{2} \mathrm{Cl}_{2}, \mathrm{ppm}\right): \delta 7.54$ (s, br, H10), 6.76 (dd, H8, 1.7, 3.6Hz), 6.37 (dd, H9, 0.7, 3.6Hz), 4.79 (q, H11, $7.3 \mathrm{~Hz}), 1.36$ (t, H12, 7.1 Hz) 7.21-7.60 (m, PPh $) .{ }^{13} \mathrm{C} \mathrm{NMR}\left(\mathrm{CD}_{2} \mathrm{Cl}_{2}, \mathrm{ppm}\right): \delta 304.8$ (C6), 220.2 (CO1), 216.8 (CO3), 211.9 (CO2), 148.7 (C10), 112.1 (C9), 112.9 (C8), 164.8 (C7), 76.9 (C11), 15.2 (C12), 129.5-130.1, 128.6, 128.5 (PPh $).{ }^{31} \mathrm{P}$ NMR $\left(\mathrm{CD}_{2} \mathrm{Cl}_{2}, \mathrm{ppm}\right): \delta 37.67 . \mathrm{IR}\left(\mathrm{KBr}, \mathrm{cm}^{-1}\right): v_{\mathrm{CO}}$ 2013 (w), 1924 (m), 1890 (m), 1865 (vs).

5-cis: Yield: $28.2 \%$, red-brown solid. ${ }^{1} \mathrm{H}$ NMR $\left(\mathrm{CD}_{2} \mathrm{Cl}_{2}, \mathrm{ppm}\right): \delta 7.77$ (dd, $\left.\mathrm{H} 8,4.0,1.1 \mathrm{~Hz}\right)$, 7.65 (dd, H10, 5.0, 1.1 Hz), 6.97 (dd, H9, 4.8, 4.0 Hz), 7.31-7.46 (m, PPh 3 ), 4.53 (dq, H11, $\left.7.0 \mathrm{~Hz}, \mathrm{~J}_{\mathrm{P}-\mathrm{H}}=0.5 \mathrm{~Hz}\right), 1.20(\mathrm{t}, \mathrm{H} 12,7.0 \mathrm{~Hz}) .{ }^{13} \mathrm{C} \mathrm{NMR}\left(\mathrm{CD}_{2} \mathrm{Cl}_{2}, \mathrm{ppm}\right): \delta 294.5\left(\mathrm{~d}, \mathrm{C} 6, \mathrm{~J}_{\mathrm{P}-\mathrm{C}}=\right.$ $7.0 \mathrm{~Hz}), 211.4\left(\mathrm{~d}, \mathrm{CO} 1, \mathrm{~J}_{\mathrm{P}-\mathrm{C}}=6.5 \mathrm{~Hz}\right), 207.3\left(\mathrm{~d}, \mathrm{CO} 3, \mathrm{~J}_{\mathrm{P}-\mathrm{C}}=24.0 \mathrm{~Hz}\right), 203.8\left(\mathrm{~d}, \mathrm{CO} 2, \mathrm{~J}_{\mathrm{P}-\mathrm{C}}=\right.$ $6.8 \mathrm{~Hz}$ ), 159.9 (C7), 140.2 (C8), 133.1 (C10), 128.7 (C9), 135.9 (d, PhC, $\mathrm{J}_{\mathrm{P}-\mathrm{C}}=38.3 \mathrm{~Hz}$ ), $133.7\left(\mathrm{~d}, \mathrm{PhC}_{\text {ortho }}, \mathrm{J}_{\mathrm{P}-\mathrm{C}}=11.8 \mathrm{~Hz}\right), 130.4\left(\mathrm{~d}, \mathrm{PhC}_{\text {pqra }}, \mathrm{J}_{\mathrm{P}-\mathrm{C}}=1.7 \mathrm{~Hz}\right), 129.0\left(\mathrm{~d}, \mathrm{PhC}_{\text {meta }}, \mathrm{J}_{\mathrm{P}-\mathrm{C}}=\right.$ 9.7 Hz), $77.8\left(\mathrm{~d}, \mathrm{C} 11, \mathrm{~J}_{\mathrm{P}-\mathrm{C}}=1.8 \mathrm{~Hz}\right), 14.8(\mathrm{C} 12) .{ }^{31} \mathrm{P} \mathrm{NMR}\left(\mathrm{CD}_{2} \mathrm{Cl}_{2}, \mathrm{ppm}\right): \delta 25.00\left(\mathrm{~d}, \mathbf{P P h}_{3}\right.$, $\left.\mathrm{J}_{\mathrm{P}-\mathrm{W}}=233.6 \mathrm{~Hz}\right) . \mathrm{IR}\left(\mathrm{KBr}, \mathrm{cm}^{-1}\right): v_{\mathrm{CO}}=2009(\mathrm{~s}), 1914(\mathrm{~s}), 1894(\mathrm{~s}), 1883(\mathrm{~s})$.

5-trans: Yield: $1.9 \%$, yellow-brown solid. ${ }^{1} \mathrm{H}$ NMR $\left(\mathrm{CD}_{2} \mathrm{Cl}_{2}, \mathrm{ppm}\right): \delta 8.01$ (dd, $\mathrm{H} 8,4.0,1.1$ $\left.\mathrm{Hz}, \mathrm{J}_{\mathrm{P}-\mathrm{H}}=0.3 \mathrm{~Hz}\right), 7.65\left(\mathrm{ddd}, \mathrm{H} 10,5.1,1.1 \mathrm{~Hz}, \mathrm{~J}_{\mathrm{P}-\mathrm{H}}=0.6 \mathrm{~Hz}\right), 7.15(\mathrm{dd}, \mathrm{H} 9,5.1,4.0 \mathrm{~Hz})$, 
7.32-7.49 (m, $\mathrm{PPh}_{3}$, meta and para), 7.50-7.58 (m, $\mathrm{PPh}_{3}$, ortho), 4.98 (q, H11, 7.0 Hz), 1.61 (t, $\mathrm{H} 12,7.0 \mathrm{~Hz}) .{ }^{13} \mathrm{C} \mathrm{NMR}\left(\mathrm{CD}_{2} \mathrm{Cl}_{2}, \mathrm{ppm}\right): \delta 283.7\left(\mathrm{~d}, \mathrm{C} 6, \mathrm{~J}_{\mathrm{P}-\mathrm{C}}=15.3 \mathrm{~Hz}\right), 205.2\left(\mathrm{~d}, \mathrm{CO}, \mathrm{J}_{\mathrm{P}-\mathrm{C}}=\right.$ $6.4 \mathrm{~Hz}$ ), 161.1 (C7), 138.9 (C8), 131.9 (C10), 128.9 (C9), 137.8 (d, PhC, J $\mathrm{J}_{\mathrm{P}-\mathrm{C}}=38.9 \mathrm{~Hz}$ ), $133.7\left(\mathrm{~d}, \mathrm{PhC}_{\text {ortho }}, \mathrm{J}_{\mathrm{P}-\mathrm{C}}=11.8 \mathrm{~Hz}\right), 130.2\left(\mathrm{~d}, \mathrm{PhC}_{\text {para }}, \mathrm{J}_{\mathrm{P}-\mathrm{C}}=1.6 \mathrm{~Hz}\right), 128.9\left(\mathrm{~d}, \mathrm{PhC}_{\text {meta }}, \mathrm{J}_{\mathrm{P}-\mathrm{C}}=\right.$ $9.5 \mathrm{~Hz}), 76.2$ (d, C11), $15.4(\mathrm{C} 12) .{ }^{31} \mathrm{P}$ NMR $\left(\mathrm{CD}_{2} \mathrm{Cl}_{2}, \mathrm{ppm}\right): \delta 22.78\left(\mathrm{~d}, \mathbf{P P h}_{3}, \mathrm{~J}_{\mathrm{P}-\mathrm{W}}=209.3\right.$ $\mathrm{Hz})$. IR (KBr, $\left.\mathrm{cm}^{-1}\right): v_{\mathrm{CO}}=2017(\mathrm{vw}), 1944(\mathrm{w}), 1892$ (s).

6-cis: Yield: $46.6 \%$, red-brown solid. ${ }^{1} \mathrm{H}$ NMR $\left(\mathrm{CD}_{2} \mathrm{Cl}_{2}, \mathrm{ppm}\right): \delta 7.30-7.43$ (m, H10), 6.80 (dd, H8, 3.6, 0.8 Hz), 6.37 (dd, H9, 3.6, 1.7 Hz), 7.30-7.43 (m, PPh $), 4.68$ (q, H11, 7.1 Hz), $1.36(\mathrm{t}, \mathrm{H} 12,7.1 \mathrm{~Hz}) .{ }^{13} \mathrm{C} \mathrm{NMR}\left(\mathrm{CD}_{2} \mathrm{Cl}_{2}, \mathrm{ppm}\right): \delta 289.0\left(\mathrm{dd}, \mathrm{C} 6, \mathrm{~J}_{\mathrm{P}-\mathrm{C}}=6.9 \mathrm{~Hz}, \mathrm{~J}_{\mathrm{W}-\mathrm{C}}=105.4\right.$ $\mathrm{Hz}), 212.3\left(\mathrm{dt}, \mathrm{CO} 1, \mathrm{~J}_{\mathrm{P}-\mathrm{C}}=6.7 \mathrm{~Hz}, \mathrm{~J}_{\mathrm{W}-\mathrm{C}}=115.5 \mathrm{~Hz}\right), 207.3\left(\mathrm{dt}, \mathrm{CO} 3, \mathrm{~J}_{\mathrm{P}-\mathrm{C}}=24.4 \mathrm{~Hz}, \mathrm{~J}_{\mathrm{W}-\mathrm{C}}=\right.$ $146.7 \mathrm{~Hz}), 203.8\left(\mathrm{dt}, \mathrm{CO} 2, \mathrm{~J}_{\mathrm{P}-\mathrm{C}}=6.9 \mathrm{~Hz}, \mathrm{~J}_{\mathrm{W}-\mathrm{C}}=128.0 \mathrm{~Hz}\right), 167.1(\mathrm{C} 7), 148.5(\mathrm{C} 10), 113.1$ (C8), $112.1(\mathrm{C} 9), 136.5\left(\mathrm{~d}, \mathrm{PhC}, \mathrm{J}_{\mathrm{P}-\mathrm{C}}=38.2 \mathrm{~Hz}\right), 133.8\left(\mathrm{~d}, \mathrm{PhC}_{\text {ortho }}, \mathrm{J}_{\mathrm{P}-\mathrm{C}}=11.8 \mathrm{~Hz}\right), 130.4(\mathrm{~d}$, $\left.\mathrm{PhC}_{\text {para }}, \mathrm{J}_{\mathrm{P}-\mathrm{C}}=1.7 \mathrm{~Hz}\right), 128.8\left(\mathrm{~d}, \mathrm{PhC}_{\text {meta }}, \mathrm{J}_{\mathrm{P}-\mathrm{C}}=9.5 \mathrm{~Hz}\right), 77.4(\mathrm{C} 11), 15.3(\mathrm{C} 12) .{ }^{31} \mathrm{P} \mathrm{NMR}$ $\left(\mathrm{CD}_{2} \mathrm{Cl}_{2}, \mathrm{ppm}\right): \delta 25.25\left(\mathrm{~d}, \mathrm{PPh}_{3}, \mathrm{~J}_{\mathrm{P}-\mathrm{W}}=236.3 \mathrm{~Hz}\right) . \mathrm{IR}\left(\mathrm{KBr}, \mathrm{cm}^{-1}\right): v_{\mathrm{CO}}=2009(\mathrm{~s}), 1921(\mathrm{~s})$, 1888 (s), 1860 (s).

6-trans: Yield: $3.3 \%$, yellow-brown solid. ${ }^{1} \mathrm{H}$ NMR $\left(\mathrm{CD}_{2} \mathrm{Cl}_{2}, \mathrm{ppm}\right): \delta 7.79(\mathrm{~s}, \mathrm{H} 10), 6.97(\mathrm{~d}$, $\mathrm{H} 8,3.5 \mathrm{~Hz}), 6.55$ (dd, H9, 3.5, 1.5 Hz), 7.32-7.48 (m, PPh 3 , meta and para), 7.52-7.60 (m, $\mathrm{PPh}_{3}$, ortho), 4.97 (q, H11, 7.0 Hz), 1.60 (t, H12, 7.0 Hz). ${ }^{13} \mathrm{C}$ NMR $\left(\mathrm{CD}_{2} \mathrm{Cl}_{2}, \mathrm{ppm}\right): \delta 278.5$ (C6), 205.0 (d, CO, J $\mathrm{P}_{-\mathrm{C}}=5.5 \mathrm{~Hz}$ ), 167.5 (C7), 147.8 (C10), 113.1 (C8), 111.2 (C9), 138.1 (d, $\left.\mathrm{PhC}, \mathrm{J}_{\mathrm{P}-\mathrm{C}}=37.6 \mathrm{~Hz}\right), 134.0\left(\mathrm{~d}, \mathrm{PhC}_{\text {ortho }}, \mathrm{J}_{\mathrm{P}_{\mathrm{C}} \mathrm{C}}=11.3 \mathrm{~Hz}\right), 130.3\left(\mathrm{PhC}_{\text {para }}\right), 129.0\left(\mathrm{~d}, \mathrm{PhC}_{\text {meta }}\right.$, $\left.\mathrm{J}_{\mathrm{P}-\mathrm{C}}=9.1 \mathrm{~Hz}\right), 76.0(\mathrm{~d}, \mathrm{C} 11), 15.6(\mathrm{C} 12) .{ }^{31} \mathrm{P} \mathrm{NMR}\left(\mathrm{CD}_{2} \mathrm{Cl}_{2}, \mathrm{ppm}\right): \delta 23.00\left(\mathrm{~d}, \mathbf{P P h}_{3}, \mathrm{~J}_{\mathrm{P}-\mathrm{W}}=\right.$ $209.3 \mathrm{~Hz})$. IR $\left(\mathrm{KBr}, \mathrm{cm}^{-1}\right): v_{\mathrm{CO}}=2019(\mathrm{vw}), 1941(\mathrm{w}), 1884(\mathrm{~s})$.

\section{Crystallography}

Data for 1-cis, 4-cis and 6-trans were collected at $150 \mathrm{~K}$ on a Bruker D8 Venture kappa geometry diffractometer, with duo I $\mu$ s sources, a Photon 100 CMOS detector and APEX II control software using Quazar multi-layer optics monochromated, Mo-K $\alpha$ radiation by means of a combination of $\phi$ and $\omega$ scans. Data reduction was performed using SAINT+ and the intensities were corrected for absorption using SADABS [16]. The structures were solved by intrinsic phasing using SHELXTS and refined by full-matrix least squares using SHELXTL and SHELXL-2013 [17]. In the structure refinement, all hydrogen atoms were added in calculated positions and treated as riding on the atom to which they are attached. All nonhydrogen atoms were refined with anisotropic displacement parameters, all isotropic displacement parameters for hydrogen atoms were calculated as $\mathrm{X} \times$ Ueq of the atom to which they are attached, $X=1.5$ for the methyl hydrogens and 1.2 for all other hydrogens. Crystallographic data and refinement parameters are given in Table 1. Ortep drawings [18] of the three structures are included in Figure 1 - Figure 3. The crystal structures (cif) have been deposited at the Cambridge Crystallographic Data Centre and allocated the deposition numbers: CCDC 969380-969382. Data collection, structure solution and refinement details are available in each cif. 
Table 1: Crystallographic data and refinement parameters

\begin{tabular}{|c|c|c|c|}
\hline Identification code & 1-cis & 4-cis & 6-trans \\
\hline Empirical formula & $\mathrm{C}_{29} \mathrm{H}_{23} \mathrm{CrO}_{5} \mathrm{P} \mathrm{S}$ & $\mathrm{C}_{29} \mathrm{H}_{23} \mathrm{Mo} \mathrm{O}_{6} \mathrm{P}$ & $\mathrm{C}_{29} \mathrm{H}_{23} \mathrm{O}_{6} \mathrm{P} \mathrm{W}$ \\
\hline Formula weight & 566.50 & 594.38 & 682.29 \\
\hline Temperature & $150(2) \mathrm{K}$ & $150(2) \mathrm{K}$ & $150(2) \mathrm{K}$ \\
\hline Wavelength & $0.71073 \AA$ & $0.71073 \AA$ & $0.71073 \AA$ \\
\hline Crystal system & Monoclinic & Monoclinic & Monoclinic \\
\hline Space group & $P 2_{1} / \mathrm{n}$ & $P 2_{1} / \mathrm{c}$ & $P 2_{1} / \mathrm{c}$ \\
\hline \multirow[t]{4}{*}{ Unit cell dimensions } & $a=9.920(3) \AA$ & $a=10.5978(9) \AA$ & $a=13.6340(5) \AA$ \\
\hline & $\mathrm{b}=27.789(3) \AA$ & $\mathrm{b}=12.6167(11) \AA$ & $\mathrm{b}=17.6322(7) \AA$ \\
\hline & $c=10.458(3) \AA$ & $c=20.5695(17) \AA$ & $c=10.8460(4) \AA$ \\
\hline & $\beta=112.662(5)^{\circ}$ & $\beta=103.29(3)^{\circ}$ & $\beta=92.284(2)^{\circ}$ \\
\hline Volume & $2660.1(13) \AA^{3}$ & $2676.7(4) \AA^{3}$ & $2605.28(17) \AA^{3}$ \\
\hline Z & 4 & 4 & 4 \\
\hline Density (calculated) & $1.415 \mathrm{Mg} / \mathrm{m}^{3}$ & $1.475 \mathrm{Mg} / \mathrm{m}^{3}$ & $1.740 \mathrm{Mg} / \mathrm{m}^{3}$ \\
\hline Absorption coefficient & $0.606 \mathrm{~mm}^{-1}$ & $0.591 \mathrm{~mm}^{-1}$ & $4.537 \mathrm{~mm}^{-1}$ \\
\hline $\mathrm{F}(000)$ & 1168 & 1208 & 1336 \\
\hline Crystal size $\left(\mathrm{mm}^{3}\right)$ & $0.211 \times 0.161 \times 0.151$ & $0.106 \times 0.089 \times 0.061$ & $0.340 \times 0.322 \times 0.230$ \\
\hline $\begin{array}{l}\text { Theta range for data } \\
\text { collection }\end{array}$ & 2.343 to $26.372^{\circ}$ & 2.488 to $25.446^{\circ}$ & 2.206 to $33.271^{\circ}$ \\
\hline Index ranges & $\begin{array}{l}-12 \leq \mathrm{h} \leq 11,-34 \leq \mathrm{k} \leq 34 \\
-12 \leq \mathrm{l} \leq 13\end{array}$ & $\begin{array}{l}-12 \leq \mathrm{h} \leq 12,-15 \leq \mathrm{k} \leq 15 \\
-24 \leq \mathrm{l} \leq 24\end{array}$ & $\begin{array}{l}-20 \leq \mathrm{h} \leq 20,-27 \leq \mathrm{k} \leq 27 \\
-16 \leq \mathrm{l} \leq 16\end{array}$ \\
\hline Reflections collected & 40447 & 69374 & 103371 \\
\hline Independent reflections & $5367[\mathrm{R}($ int $)=0.0656]$ & $4930[\mathrm{R}($ int $)=0.0932]$ & $9987[\mathrm{R}(\mathrm{int})=0.0523]$ \\
\hline $\begin{array}{l}\text { Data / restraints / } \\
\text { parameters }\end{array}$ & $5367 / 0 / 334$ & 4930 / 0 / 334 & 9987 / 0 / 196 \\
\hline Final $R$ indices $[\mathrm{I}>2 \sigma(\mathrm{I})]$ & $\begin{array}{l}\mathrm{R} 1=0.0902, \mathrm{wR} 2= \\
0.1991\end{array}$ & $\begin{array}{l}\mathrm{R} 1=0.0331, \mathrm{wR} 2= \\
0.0721\end{array}$ & $\begin{array}{l}\mathrm{R} 1=0.0762, \mathrm{wR} 2= \\
0.1844\end{array}$ \\
\hline Largest diff. peak and hole & 1.194 and -0.708 e. $\AA^{-3}$ & 0.781 and -0.336 e. $\AA^{-3}$ & 8.156 and -3.013 e. $\AA^{-3}$ \\
\hline
\end{tabular}

\section{Computational chemistry}

Density functional theory (DFT) calculations were carried out using the ADF (Amsterdam Density Functional) 2012 programme [19,20,21] with the GGA (Generalized Gradient Approximation) functional PW91 (Perdew-Wang, 1991) [22]. The TZP (triple $\zeta$ polarised) basis set with a fine mesh for numerical integration, a spin-restricted formalism and full geometry optimization with tight convergence criteria, was used for minimum energy 
searches. Throughout, all calculations have been performed in the gas phase with no symmetry constraint $\left(C_{1}\right)$ and all structures have been calculated as singlet states. The standard deviation from the average experimental value $(\bar{\theta})$ of $\mathrm{n}$ experimental values of $\boldsymbol{\theta}$ is calculated by $\sqrt{\frac{\sum(\bar{\theta}-\theta)^{2}}{n-1}}[23]$.

\section{Results and Discussion}

The structures of the triphenylphosphine-substituted Fischer carbene complexes of this study, $\left[(\mathrm{CO})_{4}\left(\mathrm{PPh}_{3}\right) \mathrm{M}=\mathrm{C}(\mathrm{OEt}) \mathrm{R}\right]$, are shown in Scheme 1 . The $\mathrm{PPh}_{3}$ group can be positioned either cis or trans to the carbene ligand $\mathrm{C}(\mathrm{OEt}) \mathrm{R}$. Crystal structures of only ten Fischer carbene complexes of the formula $\left[(\mathrm{CO})_{4}\left(\mathrm{PPh}_{3}\right) \mathrm{M}=\mathrm{C}(\mathrm{Y}) \mathrm{R}\right]$ have been reported to date [24], all of them having the $\mathrm{PPh}_{3}$ group cis to the carbene ligand $\mathrm{C}(\mathrm{Y}) \mathrm{R}$.

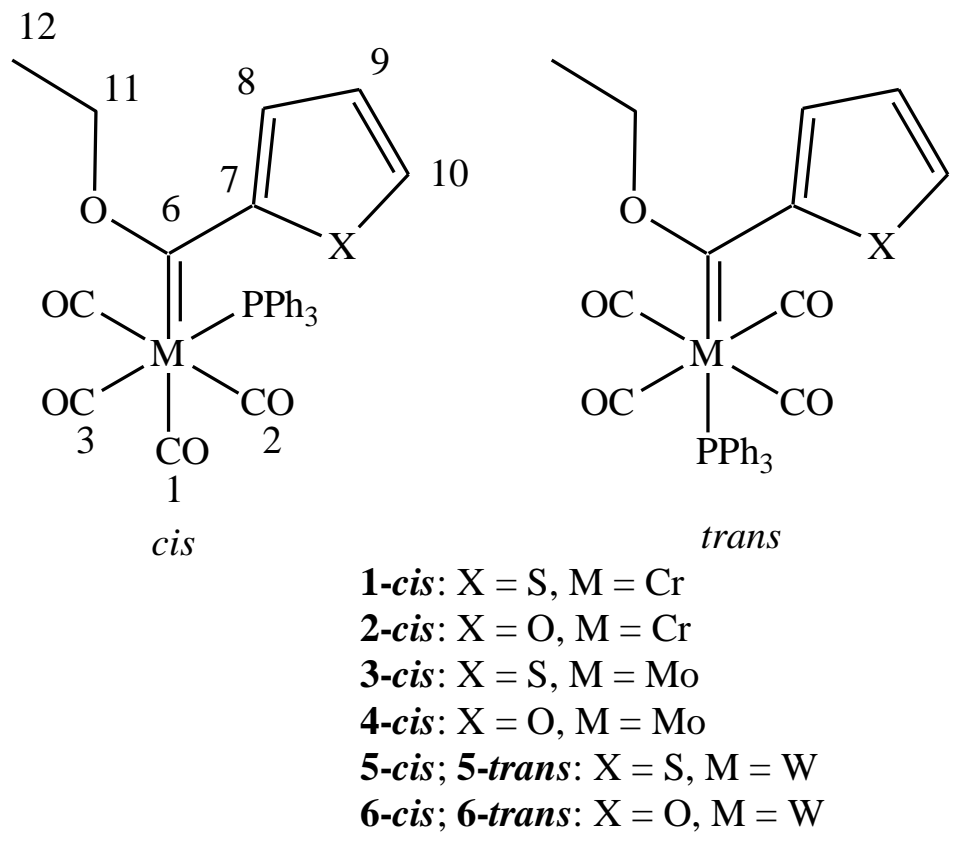

Scheme 1: Cis- and trans- $\left[(\mathrm{CO})_{4}\left(\mathrm{PPh}_{3}\right) \mathrm{M}=\mathrm{C}(\mathrm{OEt}) \mathrm{R}\right]$ complexes

\section{Synthesis}

The synthesis and purification of monophosphinated Fischer carbenes with various ligands and metals had been described in literature [25-30]. Two different synthetic procedures can be distinguished: (a) Thermal or photolytic substitution of a carbonyl ligand of the pentacarbonyl metal carbene complex $\left[(\mathrm{CO})_{5} \mathrm{M}=\mathrm{C}(\mathrm{OEt}) \mathrm{R}\right]$ by $\mathrm{PPh}_{3}$, or $(\mathrm{b})$ synthesis of the 
$\left[\left(\mathrm{PPh}_{3}\right)(\mathrm{CO})_{4} \mathrm{M}\right]$ precursor followed by classical Fischer methodology to yield the phosphinesubstituted tetracarbonyl metal carbene complex $\left[(\mathrm{CO})_{4}\left(\mathrm{PPh}_{3}\right) \mathrm{M}=\mathrm{C}(\mathrm{OEt}) \mathrm{R}\right]$. In the latter case, the monophosphinated Fischer carbene complexes are found exclusively in the cis configuration. It is suggested that the phosphine reduces the electrophilicity of the transcarbonyl carbon due to the increased backbonding from the metal, thus making it less available to react with the organolithium reagent, hence reducing the chance of the trans isomer forming. Following the thermal or photolytic substitution route, both cis and trans isomers are formed. In most cases, the trans isomers were simply too unstable to isolate, characterize and/or crystallize. Fischer and Aumann synthesized monophosphinated carbenes of molybdenum, chromium and tungsten but no crystal structures were determined [25]. The cis-conformation of these complexes was based on IR- and NMR spectroscopic data.

The parent pentacarbonyl monocarbene complexes I-VI, [11]-[14] were prepared by deprotonation of the corresponding heteroaryl ring at low temperatures, metallation and finally alkylation with $\mathrm{Et}_{3} \mathrm{OBF}_{4}$. All six complexes were bright red and hence allowed the progress of the subsequent reactions to be followed easily by monitoring the colour change from red to yellow. Complexes 1-6 were synthesized by refluxing the monocarbene complex (I-VI) in toluene with an excess of $\mathrm{PPh}_{3}$ for 8 hours. TLCs for the crude products of 1-6 showed a mixture of the cis and trans complexes was obtained in each case. A yellow-brown spot, belonging to the trans isomer, was seen slightly above a red-brown spot, which corresponded to the cis isomer. The cis isomer was generally obtained in tenfold excess to the trans isomer. Separation of the cis and trans monophosphine ethoxy carbene derivatives proved to be difficult. It was found that the trans complexes isomerize to the more stable cis complexes in solution, making it difficult to isolate a trans complex [31]. In fact, Cooke and Fischer [6] found it impossible to separate the isomers from one another. The isomers were thus separated at $-10^{\circ} \mathrm{C}$ on a silica gel column mostly by means of fraction collection, since separation of the bands were not readily observed. By this route it was possible to isolate 5trans and 6-trans; the structure of 6-trans is the first solid state X-ray structure of a trans$\left[(\mathrm{CO})_{4}\left(\mathrm{PPh}_{3}\right)\right.$-metal-carbene] to be reported.

\section{Crystal Structures}

Suitable crystals of 1-cis, 4-cis and 6-trans were obtained from DCM:Hexane (1:1) solutions and crystal structures determined with single-crystal X-ray diffraction analysis. The molecular structures of these complexes with the atom-numbering scheme are shown in 
Figure 1 - Figure 3 and compared to the structure of 6-cis [15], CSD deposition number CCDC 955033]. Selected bond lengths and angles are given in Table 2.

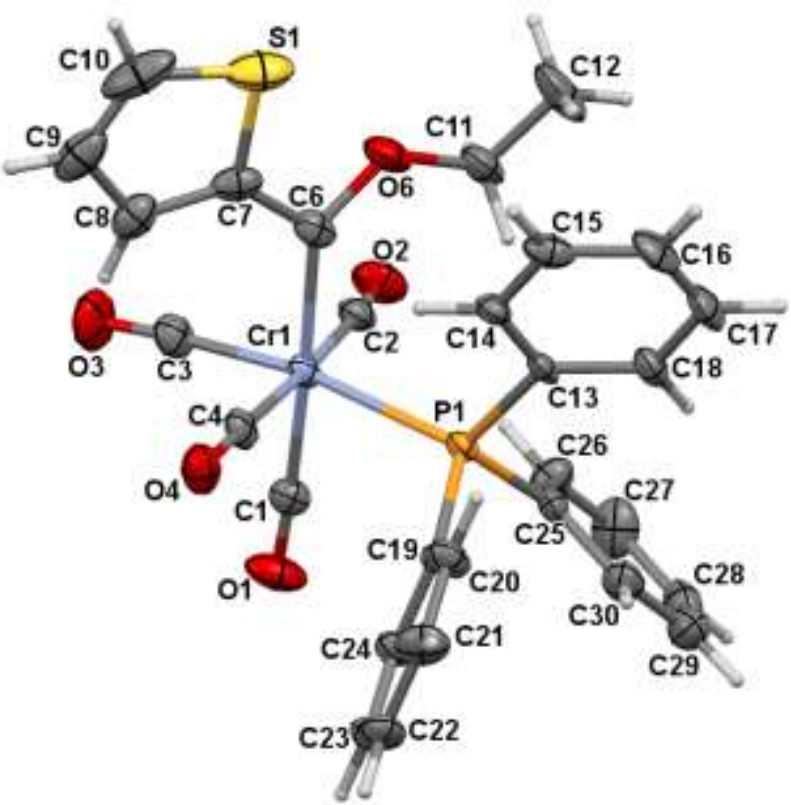

Figure 1: A perspective drawing of the molecular structure of 1-cis showing the atom numbering scheme. ADPs are shown at the $50 \%$ probability level.

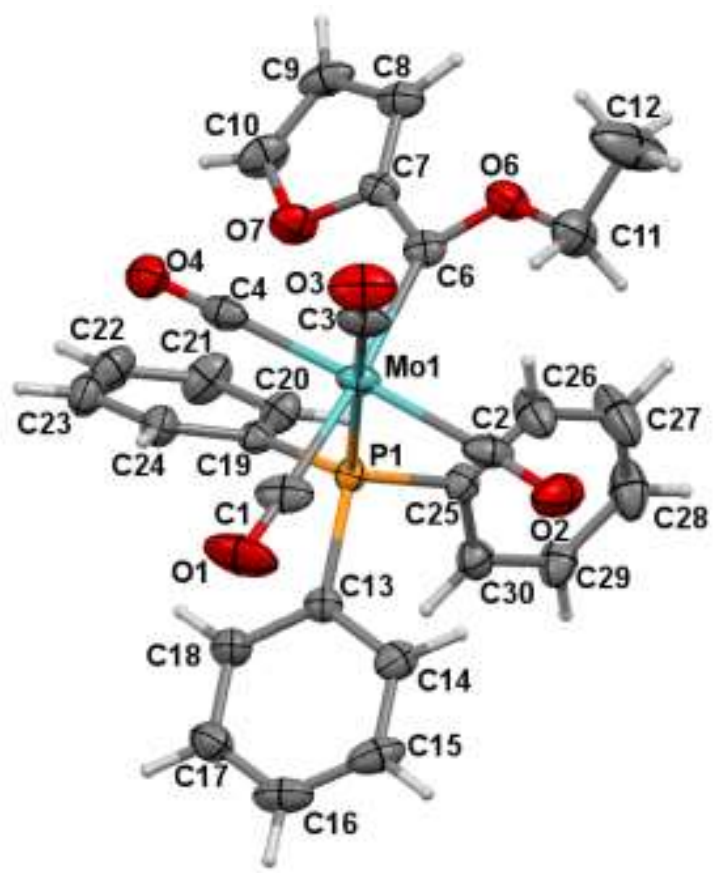

Figure 2: A perspective drawing of the molecular structure of 4-cis showing the atom numbering scheme. ADPs are shown at the $50 \%$ probability level. 


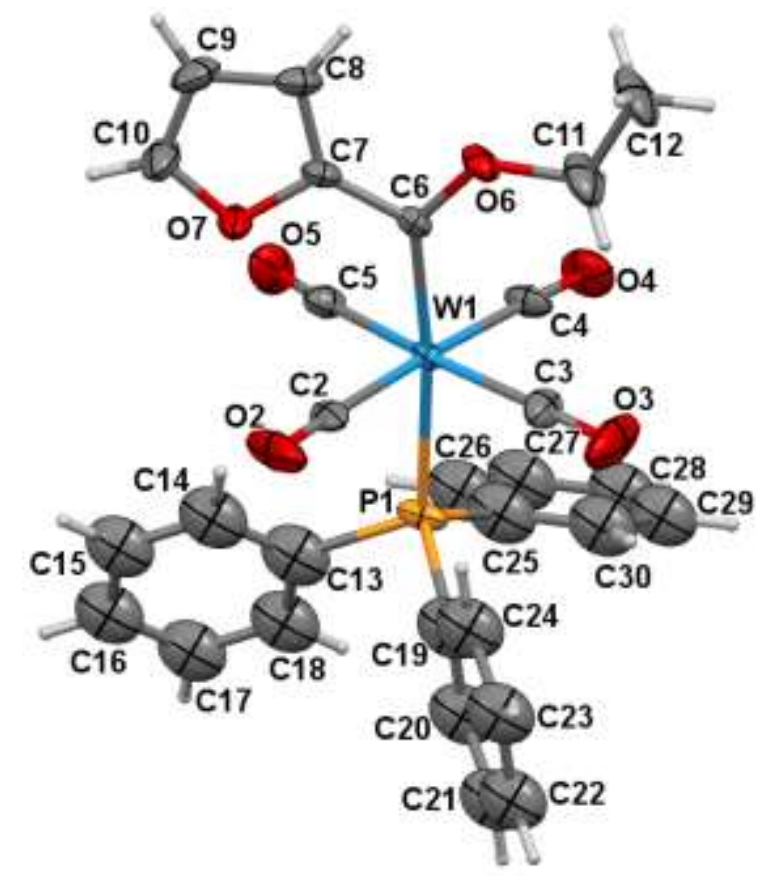

Figure 3: A perspective drawing of the molecular structure of 6-trans showing the atom numbering scheme. ADPs are shown at the $50 \%$ probability level.

The orientation of the furyl rings in both compounds 4-cis and 6-trans are such that the oxygen atom of the furyl ring is in an anti conformation relative to the oxygen atom of the ethoxy substituent. By contrast, the sulfur atom in the thienyl substituent in 1-cis is in a syn conformation. In 6-trans, the $\mathrm{PPh}_{3}$ group occupies the position trans to the carbene, while in both 1-cis and 4-cis the $\mathrm{PPh}_{3}$ groups are in cis positions. The Mo- and $\mathrm{W}$-carbene distances of 2.180(3) and 2.1712(13) $\AA$ in 4-cis and 6-cis are significantly longer that the Cr-carbene distance of 2.038(6) $\AA$ observed in 1-cis. All the $\mathrm{M}=\mathrm{C}_{\text {carbene }}$ bond lengths of the complexes in this study are consistently shorter by approximately $0.04 \AA$ than literature values for analogous pentacarbonyl complexes [13,32]. The mean metal-C bond distances for carbonyls cis to the carbene bond are similar for both Mo and W-carbene compounds 4-cis and 6-trans, but differ significantly from that of the Cr-carbene 1-cis. The conformation of the substituents on the the carbene atom (C6) of the structures are very similar in that the metal, $\mathrm{C} 6, \mathrm{O} 6, \mathrm{C} 11, \mathrm{C} 12$, and the non-hydrogen atoms of the thienyl and the furyl rings are all planar. The discernible trend of increasing $\mathrm{M}-\mathrm{CO}_{\mathrm{av}}$ bond lengths is observed down the group VI metals if one compares the three cis-complexes. Similar trends for analogous $\mathrm{Cr}$ - and W phosphine carbene complexes are found in literature [33]. 
In comparing the M-P1 bond lengths of 6-cis and 6-trans; this bond is shorter for the trans complex. The carbene ligand is a weaker $\sigma$-donor, $\pi$-acceptor ligand than a carbonyl ligand and thus the bond in the trans complex will be shorter. This argument also holds true when comparing the $\mathrm{W}-\mathrm{C} 6_{\text {carbene }}$ bond lengths of the two tungsten complexes. Since phosphines are again weaker $\sigma$-donor, $\pi$-acceptor ligands than carbonyls, the trans complex has the shorter metal-carbene bond.

Table 2: Selected geometric parameters for 1-cis, 4-cis, 6-cis and 6-trans

\begin{tabular}{|c|c|c|c|c|}
\hline Bond length $(\AA)$ & 1-cis & 4-cis & 6-cis [15] & 6-trans \\
\hline $\mathrm{M}-\mathrm{C}_{(\text {carbonyl) }}{ }^{\mathrm{a}}$ & $1.882(6)$ & $2.019(9)$ & $2.0353(17)$ & $2.024(9)$ \\
\hline $\mathrm{M}-\mathrm{C} 1^{\mathrm{b}}$ & $1.876(6)$ & $2.021(4)$ & $2.0185(17)$ & - \\
\hline M-P1 & $2.4287(16)$ & $2.562(8)$ & $2.5488(3)$ & $2.5082(19)$ \\
\hline $\mathrm{M}-\mathrm{C} 2$ & $1.888(6)$ & $2.036(3)$ & $2.031(2)$ & $2.043(8)$ \\
\hline $\mathrm{M}-\mathrm{C} 3$ & $1.867(6)$ & $1.982(3)$ & $1.9870(15)$ & $2.006(9)$ \\
\hline $\mathrm{M}-\mathrm{C} 4$ & $1.892(6)$ & $2.038(4)$ & $2.040(2)$ & $2.028(8)$ \\
\hline M-C5 & - & - & - & $2.018(8)$ \\
\hline M-C6 $6_{\text {carbene }}$ & $2.038(6)$ & $2.180(3)$ & $2.1712(13)$ & $2.119(7)$ \\
\hline C6-O6 & $1.365(7)$ & $1.329(4)$ & $1.3286(18)$ & $1.344(8)$ \\
\hline C6-C7 & $1.457(9)$ & $1.447(4)$ & $1.4475(19)$ & $1.454(11)$ \\
\hline \multicolumn{5}{|l|}{ Bond angle $\left(^{\circ}\right)$} \\
\hline C1-M-C6 & $175.3(2)$ & $174.55(13)$ & $174.24(7)$ & - \\
\hline M-C6-O6 & $130.8(5)$ & $131.5(2)$ & $130.76(10)$ & $132.5(5)$ \\
\hline M-C6-C7 & $124.9(4)$ & $124.8(2)$ & $124.70(10)$ & $124.5(5)$ \\
\hline O6-C6-C7 & $104.2(5)$ & $103.6(2)$ & $104.45(10)$ & $103.0(0)$ \\
\hline C1-M-P1 & $85.59(17)$ & $87.22(9)$ & $87.24(5)$ & - \\
\hline C6-M-P1 & $98.54(16)$ & $94.03(7)$ & $93.87(4)$ & $173.4(2)$ \\
\hline \multicolumn{5}{|l|}{ Dihedral angle $\left(^{\circ}\right)$} \\
\hline O6-C6-C7-O7/S1 & $-12.0(6)$ & $176(1)$ & $-175.64(12)$ & $170(1)$ \\
\hline M-C6-C7-O7/S1 & $170.0(3)$ & $-8(1)$ & $7.60(18)$ & $-9(1)$ \\
\hline P1-M-C6-O6 & $60.6(5)$ & $-123(1)$ & $122.7(1)$ & $-164(1)$ \\
\hline M-C6-O6-C11 & $-3.7(3)$ & $1(1)$ & $-0.3(2)$ & $-9(1)$ \\
\hline
\end{tabular}

${ }^{a}$ Average bond distances of carbonyl cis to carbene bond

${ }^{\mathrm{b}}$ Bond distances for carbonyl trans to carbene bond 


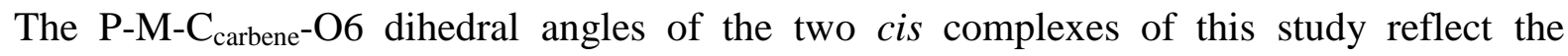
staggered nature of the ligand conformation relative to the carbene moiety. In most cases, the values of the dihedral angles $\mathrm{P}-\mathrm{M}-\mathrm{C}_{\text {carbene }} \mathrm{X}(\mathrm{X}=\mathrm{O}, \mathrm{N})$ of the cis complexes reported in literature (table 3 ) display a similar staggered conformation, with values close to $60^{\circ}$ or $120^{\circ}$. The only exceptions are the two complexes QESYUI [33b], where one of the two molecules in the asymmetric unit displays an eclipsed conformation $\left(-93.3^{\circ}\right)$ and one a staggered conformation $\left(-67.9^{\circ}\right)$, and GOFXOP [34], which also exhibits an eclipsed conformation $\left(95.6^{\circ}\right)$. For 6-trans, the $\mathrm{P}-\mathrm{W}-\mathrm{C}_{\text {carbene }}-\mathrm{O}$ dihedral is $-164(1)^{\circ}$.

\section{Conformation of $\mathrm{PPh}_{3}$ in cis- and trans- $\left[(\mathrm{CO})_{4}\left(\mathrm{PPh}_{3}\right) \mathrm{ML}\right]$ complexes}

The phenyl rings of the free $\mathrm{PPh}_{3}$ molecule adopt a propeller-like $C_{3}$-symmetrical conformation that are oriented in a clockwise or counter clockwise fashion, see Figure 4 [35]. In solution, fast inversion between the two helicities occur [36], the barrier to inversion is low [37], and the two conformations are equi-energetic. In Figure 5 geometrical parameters related to the rotation of $\mathrm{PPh}_{3}$, are defined. The three phenyl rings attached to $\mathrm{P}$, indicated by $\mathrm{A}, \mathrm{B}$ and $\mathrm{C}$, will be referred to as $\mathrm{Ph}_{\mathrm{A}}, \mathrm{Ph}_{\mathrm{B}}$ and $\mathrm{Ph}_{\mathrm{C}}$. The vector perpendicular to the reference plane and incident upon the $\mathrm{P}$ atom is used as an axis of chirality and referred to as the $\sigma_{\mathrm{nb}}-\mathrm{P}$ axis. Rotation around the $\sigma_{\mathrm{nb}}-\mathrm{P}$ axis is referred to as $\theta$. When $\mathrm{PPh}_{3}$ is bonded to a metal, $\theta$ describes the rotation of $\mathrm{PPh}_{3}$ about the M-P bond, i.e. dihedral (torsion) angle L-M$\mathrm{P}-\mathrm{C}_{\mathrm{i}}$, where $\mathrm{L}$ denotes a ligand attached to $\mathrm{M}$. Rotation about a $\mathrm{P}-\mathrm{C}_{\mathrm{Ph}}$ bond is referred to as $\omega$, i.e. the dihedral (torsion) angle M-P- $\mathrm{C}_{\mathrm{i}}-\mathrm{C}_{\mathrm{o}},\left(\mathrm{C}_{\mathrm{i}}=\mathrm{C}_{\mathrm{ipso}}\right.$ and $\mathrm{C}_{\mathrm{o}}=\mathrm{C}_{\text {ortho }}$ of the phenyl ring $\mathrm{Ph})$. Average crystallographically obtained values of $\omega_{\mathrm{A}}\left(-56^{\circ}\right), \omega_{\mathrm{B}}\left(-27^{\circ}\right)$ and $\omega_{\mathrm{C}}\left(-25^{\circ}\right)$ of free $\mathrm{PPh}_{3}$ correlate reasonably well with the calculated value of $-50 \pm 10^{\circ}$, using molecular modelling calculations [37]. The observed distortion of molecular symmetry in the crystal state is considered consistent with packing effects [37,38].

When $\mathrm{PPh}_{3}$ is coordinated to a metal, rotation along the M-P and $\mathrm{P}-\mathrm{Ph}$ axes occurs to minimize both inter ring-ligand and inter ring-ring interactions. However, the preferred orientation of complex-bound $\mathrm{PPh}_{3}$ in the solid state generally appears to be the same, as illustrated in Figure 6. The orientation of $\mathrm{PPh}_{3}$ relative to the ligands of the complex it is attached to, depends if the complex is tetrahedral, trigonal bipyramidal [37], square planar [39] or octahedral [40]. It was found that the minimum energy orientation of complex-bound $\mathrm{PPh}_{3}$ in the solid state generally can be related to the "plane of nadir energy", a concept used 
by Costello and Davies to describe the plane bisecting any two geminal ligands, linking all points of minimum steric compression between the ligands [37]. In all cases $\mathrm{PPh}_{3}$ is preferably orientated in such a way that the interaction between the phenyl rings and the ligands is minimized, i.e. the phenyl rings are arranged as near as possible to the plane of nadir energy. Correlated tilting of the phenyl rings occur, depending on the relative size of the ligands, to minimize inter ring-ring and inter ring-ligand interactions.
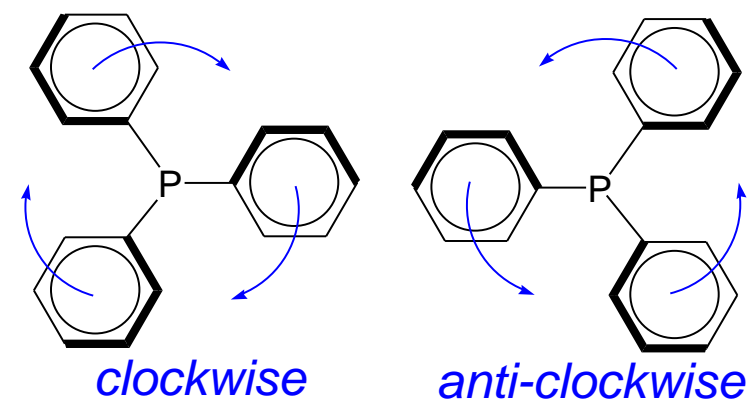

Figure 4: A representation demonstrating the enantiomeric clockwise and anti-clockwise configurations of $\mathrm{PPh}_{3}$

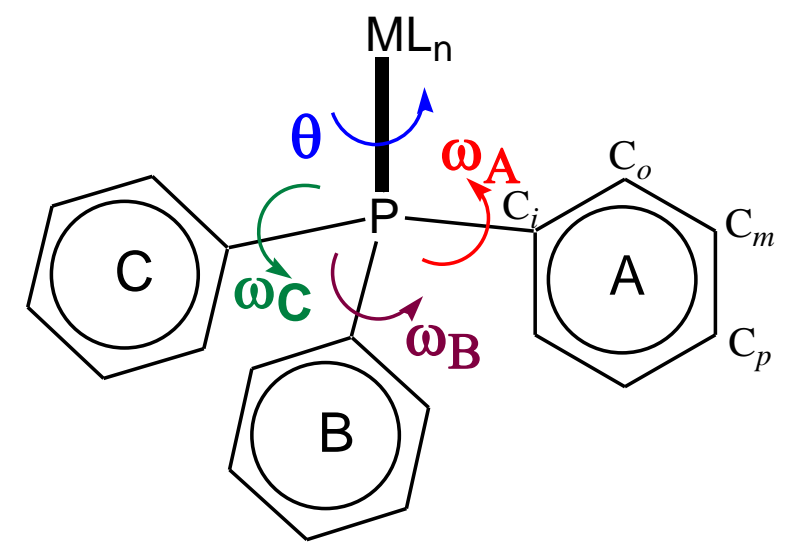

Figure 5: Definition of dihedral angle $\omega$ (rotation of a phenyl ring about $\mathrm{P}-\mathrm{C}_{\mathrm{Ph}}$ bond) and $\theta$ (rotation of $\mathrm{PPh}_{3}$ about M-P bond). The phenyl rings are numbered $\mathrm{A}, \mathrm{B}$ and $\mathrm{C}$. The $\mathrm{C}$ and $\mathrm{H}$ on the phenyl rings will be referred to as ipso, ortho, meta and para (indicated on ring A). 

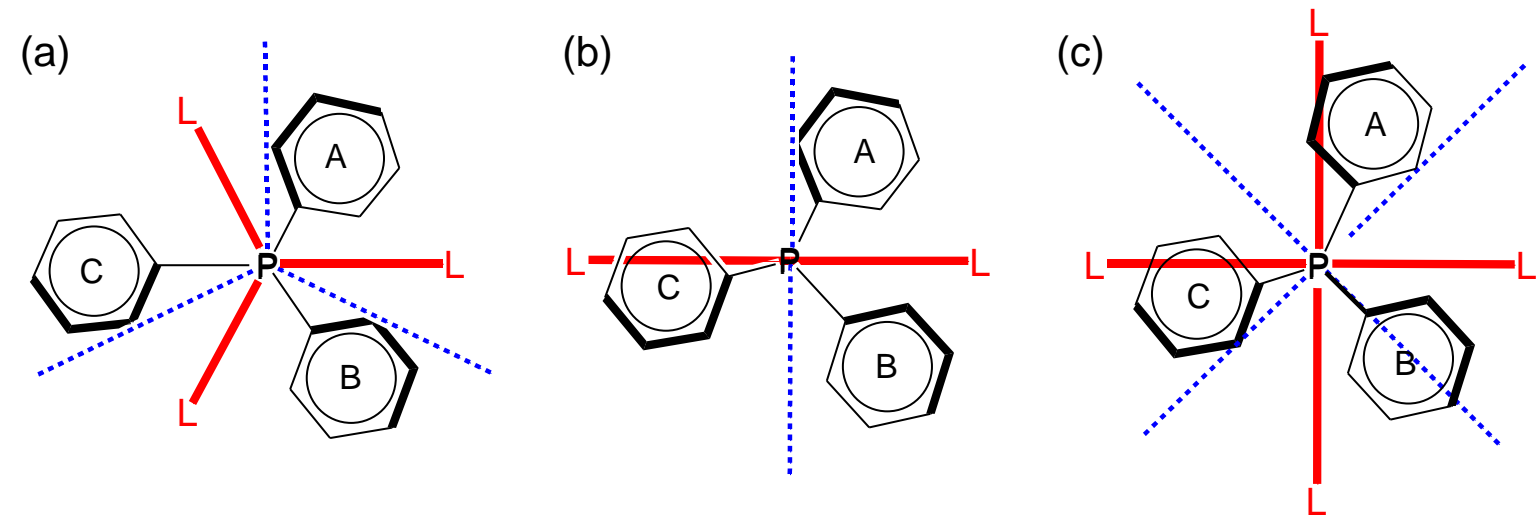

Figure 6: A schematic presentation of the preferred orientation of complex-bound $\mathrm{PPh}_{3}$ relative to the ligands $\mathrm{L}$ and the planes of nadir energy (blue dotted lines) when coordinated to (a) a tetrahedral or trigonal-bipyramidal metal centre, (b) a square planar metal centre or (c) an octahedral metal centre, as viewed along the P-metal axis.

Crystal structures of $\mathrm{PPh}_{3}$-containing complexes generally exist as a racemic mixture consisting of units from each helicity in the same unit cell, therefore units with the clockwise orientation will mainly be presented and discussed in this section.

The orientation of $\mathrm{PPh}_{3}$ in cis- $\left[(\mathrm{CO})_{4}\left(\mathrm{PPh}_{3}\right) \mathrm{M}\right.$-carbene] complexes is shown in Figure 7 and data of the available cis-[(CO) ${ }_{4}\left(\mathrm{PPh}_{3}\right) \mathrm{M}$-carbene] complexes [41] is summarized in Table 3. The interesting observation is that experimentally there seems to be no preference of the position of the cis ligand $\mathrm{L}$ relative to the typical $\mathrm{PPh}_{3}$ orientation shown in the top left of Figure 7. Furthermore, the orientation of the $\mathrm{P}-\mathrm{C}_{i}$ bonds, as expressed in terms of rotation around the M-P bond, $\theta$, in all the complexes are very similar, see Table 3 for the values. The same $\mathrm{PPh}_{3}$ orientation is observed in the cis-[(CO) ${ }_{4}\left(\mathrm{PPh}_{3}\right) \mathrm{M}$-carbene] complexes 1-cis, 4-cis and 6-cis [15], see Figure 7 top. 


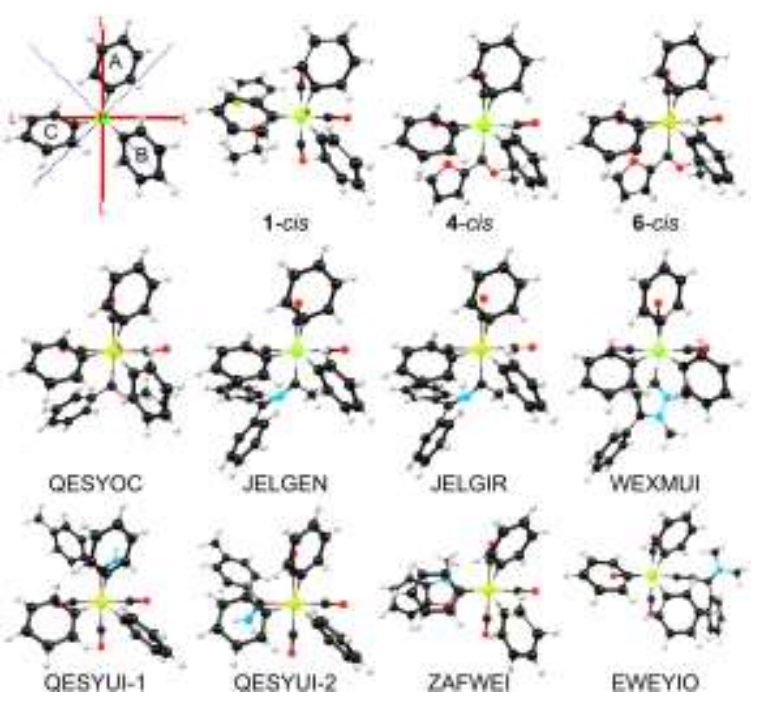

Figure 7: A representation of the $\mathrm{PPh}_{3}$ orientation in of crystals of cis-[(CO) ${ }_{4}\left(\mathrm{PPh}_{3}\right) \mathrm{M}$-carbene] complexes as viewed along the P-M axis. Top left: the typical orientation. Complex numbers and CSD reference codes are shown. Only clockwise orientations are shown.

Table 3: Crystallographical data for cis-[(CO) ${ }_{4}\left(\mathrm{PPh}_{3}\right) \mathrm{M}$-carbene $]$ complexes. Data are for clockwise orientation. See Figure 6 (c) for phenyl ring numbering.

\begin{tabular}{|c|c|c|c|c|}
\hline No/CSD code & Formula & $\theta_{\mathrm{A}}$ & $\theta_{\mathrm{B}}$ & $\theta_{\mathrm{C}}$ \\
\hline 1-cis & $c i s-\left[(\mathrm{CO})_{4}\left(\mathrm{PPh}_{3}\right) \mathrm{Cr}=\mathrm{C}(\mathrm{OEt})(\mathrm{Th})\right]$ & 65.5 & -45.5 & -176.4 \\
\hline 4-cis & $\operatorname{cis}-\left[(\mathrm{CO})_{4}\left(\mathrm{PPh}_{3}\right) \mathrm{Mo}=\mathrm{C}(\mathrm{OEt})(\mathrm{Fu})\right]$ & 71.5 & -44.8 & -169.3 \\
\hline 6-cis & $c i s-\left[(\mathrm{CO})_{4}\left(\mathrm{PPh}_{3}\right) \mathrm{W}=\mathrm{C}(\mathrm{OEt})(\mathrm{Fu})\right]$ & 71.0 & -45.1 & -169.7 \\
\hline QESYOC & $c i s-\left[(\mathrm{CO})_{4}\left(\mathrm{PPh}_{3}\right) \mathrm{W}=\mathrm{C}(\mathrm{OEt})(\mathrm{Ph})\right]$ & 71.3 & -48.3 & -168.0 \\
\hline JELGEN & cis- $\left[(\mathrm{CO})_{4}\left(\mathrm{PPh}_{3}\right) \mathrm{Cr}=\mathrm{C}\left(\mathrm{NPh}_{2}\right)(\mathrm{Me})\right]$ & 75.6 & -41.7 & -165.5 \\
\hline JELGIR & cis- $\left[(\mathrm{CO})_{4}\left(\mathrm{PPh}_{3}\right) \mathrm{W}=\mathrm{C}\left(\mathrm{NPh}_{2}\right)(\mathrm{Me})\right]$ & 74.8 & -42.6 & -166.0 \\
\hline WEXMUI & $\begin{array}{l}\text { cis- }\left[(\mathrm{CO})_{4}\left(\mathrm{PPh}_{3}\right) \mathrm{Cr}=\mathrm{C}(1,2-\text { Dimethyl-3-phenyl- }\right. \\
\text { pyrazol-5-ylidene })]\end{array}$ & 85.4 & -33.4 & -155.9 \\
\hline QESYUI-1 & $c i s-\left[(\mathrm{CO})_{4}\left(\mathrm{PPh}_{3}\right) \mathrm{W}=\mathrm{C}\left(\mathrm{NH}_{2}\right)(p-\mathrm{Tol})\right]$ & 80.9 & -38.0 & -158.0 \\
\hline QESYUI-2 & $c i s-\left[(\mathrm{CO})_{4}\left(\mathrm{PPh}_{3}\right) \mathrm{W}=\mathrm{C}\left(\mathrm{NH}_{2}\right)(p-\mathrm{Tol})\right]$ & 78.4 & -41.4 & -161.4 \\
\hline ZAFWEI & $\begin{array}{l}\text { cis- }\left[(\mathrm{CO})_{4}\left(\mathrm{PPh}_{3}\right) \mathrm{W}=\mathrm{C}(\mathrm{N}-\mathrm{Methyl}-1,2-\right. \\
\text { dihydrobenzoxazol-2-ylidene })]\end{array}$ & 66.5 & -51.9 & -174.3 \\
\hline EWEYIO & $\operatorname{cis}-\left[(\mathrm{CO})_{4}\left(\mathrm{PPh}_{3}\right) \mathrm{Cr}=\mathrm{C}=\mathrm{C}=\mathrm{C}\left(\mathrm{NMe}_{2}\right)(\mathrm{Ph})\right]$ & 65.8 & -53.2 & -173.9 \\
\hline GOFXOP & $c i s-\left[(\mathrm{CO})_{4}\left(\mathrm{PPh}_{3}\right) \mathrm{W}=\mathrm{C}(\mathrm{OEt})\left(\mathrm{P}\left(\mathrm{N}^{i} \mathrm{Pr}_{2}\right)_{2}\right)\right]$ & 69.7 & -52.2 & -170.4 \\
\hline \multirow[t]{3}{*}{ MEJLAO } & $\begin{array}{l}\text { cis- }\left[(\mathrm{CO})_{4}\left(\mathrm{PPh}_{3}\right) \mathrm{W}=\mathrm{C}(1,3 \text {-dibenzylimidazolidin-2- }\right. \\
\text { ylidene })]\end{array}$ & 76.6 & -41.6 & -158.1 \\
\hline & Average & 73.3 & -44.6 & -166.7 \\
\hline & Standard deviation & 6.0 & 5.8 & 6.6 \\
\hline
\end{tabular}


Since no crystal structures of trans-[(CO) $\left(\mathrm{PPh}_{3}\right) \mathrm{M}$-carbene] complexes have been available to date, the orientation of $\mathrm{PPh}_{3}$ in trans-[(CO) $\left.{ }_{4}\left(\mathrm{PPh}_{3}\right) \mathrm{ML}\right]$ complexes, with $\mathrm{PPh}_{3}$ trans to $\mathrm{L}$, will be considered. To evaluate the preferred orientation of $\mathrm{PPh}_{3}$ in trans-[(CO) $\left.{ }_{4}\left(\mathrm{PPh}_{3}\right) \mathrm{ML}\right]$, the $\mathrm{PPh}_{3}$ orientation in available crystals of trans-[(CO) $\left.)_{4}\left(\mathrm{PPh}_{3}\right) \mathrm{ML}\right]$ [42] is illustrated in Figure 8. The trans-[(CO) $\left.)_{4}\left(\mathrm{PPh}_{3}\right) \mathrm{ML}\right]$ complexes can be divided into three groups: (i) $\mathrm{L}=\mathrm{a}$ small symmetrical ligand such as $\mathrm{CO}$, I or $\mathrm{CS}$, (ii) $\mathrm{L}=\mathrm{PPh}_{3}, \mathrm{P}(\mathrm{OPh})_{3}, \mathrm{P}(\mathrm{OMe})_{3}$ or (iii) $\mathrm{L}=$ another $\mathrm{M}(\mathrm{CO})_{4}$-unit. We observe that, irrespective of the size of the trans ligand, the orientation of the $\mathrm{P}-\mathrm{C}_{i}$ bonds in all the complexes are very similar. Distinct features of the $\mathrm{PPh}_{3}$ orientation are (ring numbering is as shown in Figure 6(c)) that $\mathrm{Ph}_{\mathrm{B}}$ is orientated onto a nadir plane with the $\mathrm{P}-\mathrm{C}_{i}$ of $\mathrm{Ph}_{\mathrm{B}}$ near parallel to the nadir plane, $\mathrm{C}_{m}$ of both $\mathrm{Ph}_{\mathrm{C}}$ and $\mathrm{Ph}_{\mathrm{A}}$ is orientated as near as possible to a nadir plane, orthogonal to the $\mathrm{Ph}_{\mathrm{B}}$, with a correlated tilting of the phenyl groups. The orientation of the $\mathrm{P}-\mathrm{C}_{i}$ bonds, as expressed in terms of rotation around the M-P bond, $\theta$, is within experimental accuracy the same for the cis$\left[(\mathrm{CO})_{4}\left(\mathrm{PPh}_{3}\right) \mathrm{M}\right.$-carbene $]$ complexes (Table 3$)$ and trans- $\left[(\mathrm{CO})_{4}\left(\mathrm{PPh}_{3}\right) \mathrm{ML}\right]$-complexes $($ Table 4).

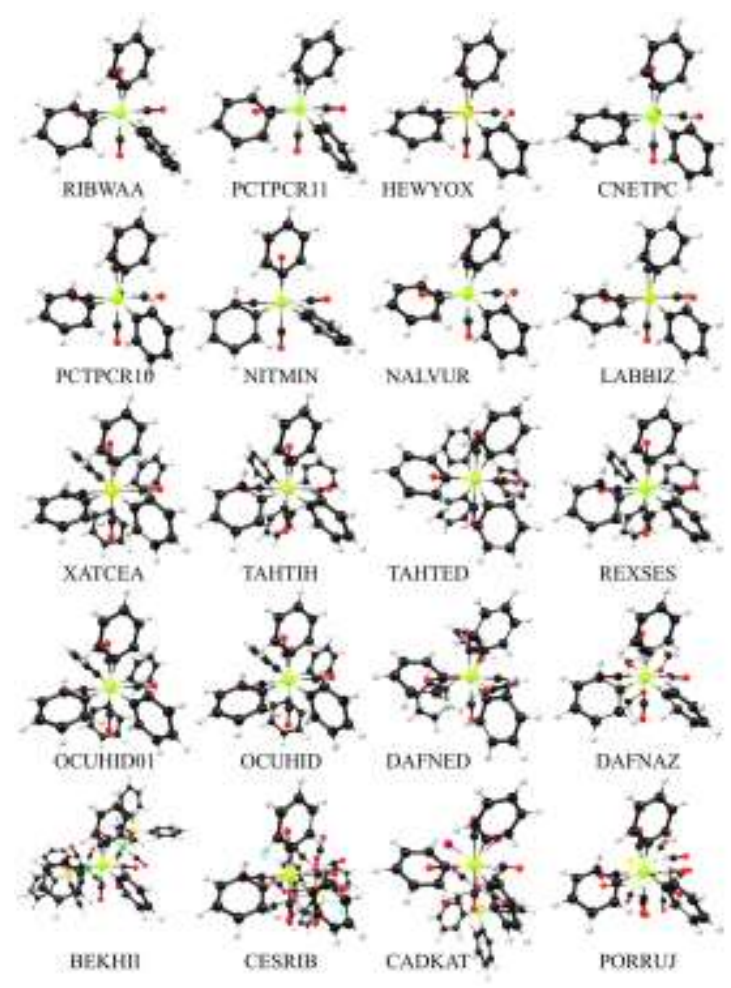

Figure 8: A representation of the $\mathrm{PPh}_{3}$ orientation in of crystals of trans- $\left[(\mathrm{CO})_{4}\left(\mathrm{PPh}_{3}\right) \mathrm{ML}\right]$ complexes. (For clarity the same helicities are shown) as viewed along the P-M axis. CSD reference codes are shown. 
Table 4: Crystallographic data for trans-[(CO) $\left.{ }_{4}\left(\mathrm{PPh}_{3}\right) \mathrm{ML}\right]$ complexes. Data are for clockwise orientation. See Figure 6 (c) for phenyl ring numbering

\begin{tabular}{|c|c|c|c|c|}
\hline $\mathrm{No} / \mathrm{CSD}$ code & Formula & $\theta_{\mathrm{A}}$ & $\theta_{\mathrm{B}}$ & $\theta_{\mathrm{C}}$ \\
\hline RIBWAA & trans $-\left[(\mathrm{CO})_{4}\left(\mathrm{PPh}_{3}\right) \mathrm{Cr}(\mathrm{CS})\right]$ & 73.7 & -45.8 & -166.8 \\
\hline PCTPCR10 & {$\left[(\mathrm{CO})_{5}\left(\mathrm{PPh}_{3}\right) \mathrm{Cr}\right]$} & 73.1 & -44.9 & -166.7 \\
\hline PCTPCR11 & {$\left[(\mathrm{CO})_{5}\left(\mathrm{PPh}_{3}\right) \mathrm{Cr}\right]$} & 71.3 & -47.6 & -168.9 \\
\hline HEWYOX & {$\left[(\mathrm{CO})_{5}\left(\mathrm{PPh}_{3}\right) \mathrm{W}\right]$} & 74.5 & -43.3 & -165.3 \\
\hline CNETPC & {$\left[(\mathrm{CO})_{5}\left(\mathrm{PPh}_{3}\right) \mathrm{Mo}\right]$} & 74.9 & -42.6 & -165.0 \\
\hline NITMIN & {$\left[(\mathrm{CO})_{5}\left(\mathrm{PPh}_{3}\right) \mathrm{Tc}\right]^{+}$} & 83.4 & -35.5 & -155.4 \\
\hline NALVUR & {$\left[(\mathrm{CO})_{5}\left(\mathrm{PPh}_{3}\right) \mathrm{V}\right]^{-}$} & 70.7 & -47.2 & -169.4 \\
\hline LABBIZ & trans $-\left[(\mathrm{CO})_{4}\left(\mathrm{PPh}_{3}\right) \mathrm{ReI}\right]$ & 73.9 & -43.9 & -165.4 \\
\hline XATCEA & trans $-\left[(\mathrm{CO})_{4}\left(\mathrm{PPh}_{3}\right)_{2} \mathrm{~W}\right]$ & 74.7 & -43.3 & -163.6 \\
\hline TAHTIH & trans $-\left[(\mathrm{CO})_{4}\left(\mathrm{PPh}_{3}\right) \mathrm{Ru}\right]^{2+}$ & 83.1 & -35.3 & -156.0 \\
\hline TAHTED & trans $-\left[(\mathrm{CO})_{4}\left(\mathrm{PPh}_{3}\right) \mathrm{Ru}\right]\left[\mathrm{BF}_{4}\right]_{2}$ & 60.9 & -59.8 & -179.8 \\
\hline REXSES & trans $-\left[(\mathrm{CO})_{4}\left(\mathrm{PPh}_{3}\right)_{2} \mathrm{Mo}\right]$ & 77.1 & -40.6 & -162.7 \\
\hline OCUHID & trans $-\left[(\mathrm{CO})_{4}\left(\mathrm{PPh}_{3}\right)_{2} \mathrm{Cr}\right]$ & 76.4 & -42.2 & -162.1 \\
\hline OCUHID01 & trans $-\left[(\mathrm{CO})_{4}\left(\mathrm{PPh}_{3}\right)_{2} \mathrm{Cr}\right]$ & 75.5 & -42.7 & -162.7 \\
\hline DAFNED & trans $-\left[(\mathrm{CO})_{4}\left(\mathrm{PPh}_{3}\right) \mathrm{Cr}\left\{\mathrm{P}(\mathrm{OPh})_{3}\right\}\right]$ & 65.4 & -53.7 & -175.4 \\
\hline DAFNAZ & trans $-\left[(\mathrm{CO})_{4}\left(\mathrm{PPh}_{3}\right) \mathrm{Cr}\left\{\mathrm{P}(\mathrm{OMe})_{3}\right\}\right]$ & 83.1 & -35.4 & -155.8 \\
\hline BEKHII & trans $-\left[\operatorname{Sn}\left\{(\mathrm{CO})_{4}\left(\mathrm{PPh}_{3}\right) \mathrm{Mn}\right\}_{3} \mathrm{Br}\right]$ & 79.3 & -38.2 & -158.6 \\
\hline CESRIB & trans $-\left[\operatorname{Sn}\left\{(\mathrm{CO})_{4}\left(\mathrm{PPh}_{3}\right) \operatorname{Re}\right\} \mathrm{I}\right]_{2}$ & 80.6 & -40.5 & -160.4 \\
\hline CADKAT & trans $-\left[\operatorname{Sn}\left\{(\mathrm{CO})_{4}\left(\mathrm{PPh}_{3}\right) \mathrm{Re}\right\}_{2} \mathrm{Br}_{2}\right]$ & 66.4 & -51.1 & -174.7 \\
\hline \multirow[t]{3}{*}{ PORRUJ } & trans- $\left[\left\{(\mathrm{CO})_{4}\left(\mathrm{PPh}_{3}\right) \mathrm{Os}\right\}\{\mathrm{Au}\}^{\mathrm{a}}\right]$ & 78.7 & -37.8 & -160.3 \\
\hline & Average & 74.8 & -43.6 & -164.7 \\
\hline & Standard deviation & 6.0 & 6.3 & 6.6 \\
\hline
\end{tabular}

${ }^{\mathrm{a}}$ Gold-Osmium cluster

In summary, available crystal data of cis-[(CO) $\left(\mathrm{PPh}_{3}\right) \mathrm{M}$-carbene $]$ and trans$\left[(\mathrm{CO})_{4}\left(\mathrm{PPh}_{3}\right) \mathrm{ML}\right]$ complexes show that the orientation of the $\mathrm{PPh}_{3}$ group in this class of octahedral complexes is generally very similar and has some distinct features, that can be described in terms of the "plane of nadir energy" [37,40] (clockwise orientations, phenyl ring numbering according to Figure $6(\mathrm{c})): \mathrm{Ph}_{\mathrm{B}}$ is orientated onto a nadir plane with the $\mathrm{P}-\mathrm{C}_{i}$ of $\mathrm{Ph}_{\mathrm{B}}$ near parallel to the nadir plane, $\mathrm{C}_{m}$ of both $\mathrm{Ph}_{\mathrm{C}}$ and $\mathrm{Ph}_{\mathrm{A}}$ is orientated as near as possible to a nadir plane, orthogonal to the $\mathrm{P}_{-} \mathrm{C}_{i}$ bond of $\mathrm{Ph}_{\mathrm{B}}$, with a correlated tilting of the phenyl groups. Surprisingly, the orientation of the $\mathrm{P}-\mathrm{Ph}$ bonds, as well as the tilting of the phenyl groups in 6-trans, deviates from this, see Figure 9. 


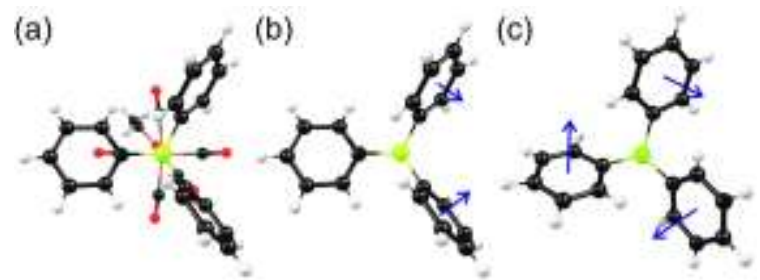

Figure 9: $\mathrm{A}$ representation of the $\mathrm{PPh}_{3}$ orientation in (a) 6-trans and (b) 6-trans without the $(\mathrm{CO})_{4} \mathrm{~W}=\mathrm{C}(\mathrm{OEt}) \mathrm{Fu}-$ moiety (for clarity) and (c) the general orientation of $\mathrm{PPh}_{3}$ in octahedral $\left[(\mathrm{CO})_{4}\left(\mathrm{PPh}_{3}\right) \mathrm{ML}\right]$ complexes

\section{DFT study of $P P h_{3}$ conformation in trans- $\left[(\mathrm{CO})_{4}\left(\mathrm{PPh}_{3}\right) \mathrm{ML}\right]$ complexes}

Since the orientation of $\mathrm{PPh}_{3}$ in 6-trans differs from the generally preferred orientation observed in trans-[(CO) $\left.)_{4}\left(\mathrm{PPh}_{3}\right) \mathrm{ML}\right]$ complexes, a DFT conformation analysis of 6-trans is presented. To validate the DFT method used, a conformation analysis of a related complex, $\left[(\mathrm{CO})_{5}\left(\mathrm{PPh}_{3}\right) \mathrm{W}\right]$ (HEWYOX in Figure 8), in which the experimental $\mathrm{PPh}_{3}$ orientation is as expected (Figure 9(c)), is presented. Figure 10 shows a potential energy surface (PES) of $\left[(\mathrm{CO})_{5}\left(\mathrm{PPh}_{3}\right) \mathrm{W}\right]$. The relative energy (in a.u.) of different conformations of $\mathrm{PPh}_{3}$ as a function of $\omega$ (rotation of a phenyl ring about $\mathrm{P}-\mathrm{C}_{\mathrm{Ph}}$ bond) and $\theta$ (rotation of $\mathrm{PPh}_{3}$ about W-P bond) is presented. The PES obtained by rotation of the $\mathrm{PPh}_{3}$ group through $360^{\circ}$ and the simultaneous rotation of a phenyl ring through $180^{\circ}$ from -70 to $110^{\circ}$, results in 703 restrained optimizations. Each of the different 703 points on the graph presents a conformation of $\left[(\mathrm{CO})_{5}\left(\mathrm{PPh}_{3}\right) \mathrm{W}\right]$ with two dihedrals related to a phenyl ring restricted and the rest of the complex fully optimized. The other two phenyl rings were thus free to rotate in order to minimize inter ring-ring and inter ring-ligand interactions towards a lower electronic energy geometry. The PES results in 12 areas of minimum energy, representing two enantiomeric minimum energy $\mathrm{PPh}_{3}$ orientations. Re-optimization of the 12 minimum energy geometries, without any constraints, resulted in two equi-energy enantiomers illustrated in Figure 11. A remarkable agreement is obtained between the experimental and calculated orientation of the P-C $C_{i}$ bonds: $\theta_{\mathrm{A}}=74.5^{\circ}, 76.9^{\circ}(\exp$, calc $) ; \theta_{\mathrm{B}}=-43.3^{\circ},-42.9^{\circ}$ (exp, calc) and $\theta_{\mathrm{C}}=-165.3^{\circ},-163.8^{\circ}$ (exp, calc). Slight differences are observed in the tilting of the phenyl rings, especially ring B is tilted more in the calculated than in the experimental structure, but phenyl groups of $\mathrm{PPh}_{3}$ are still orientated in the same direction, see the overlay in Figure 11(b). 


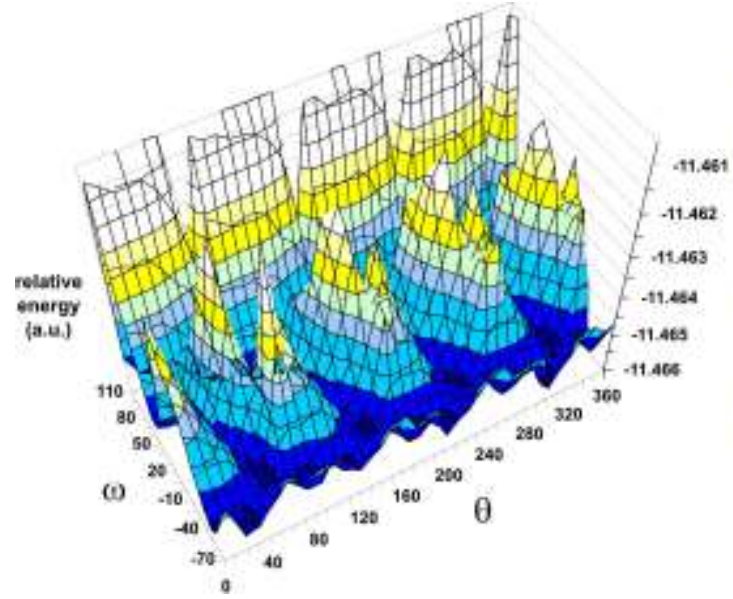

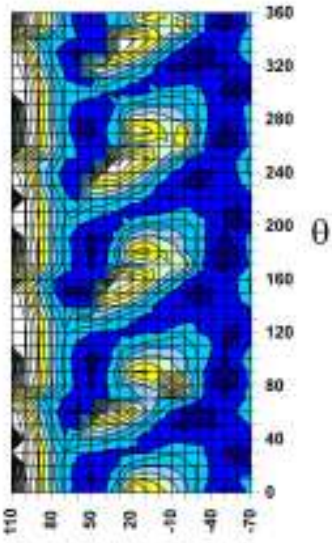

$\omega$

Figure 10: A 3-D (left) and 2-D (middle) potential energy surface (PES) of $\left[(\mathrm{CO})_{5}\left(\mathrm{PPh}_{3}\right) \mathrm{W}\right]$ representing the relative energy (in a.u.) of different conformations of $\mathrm{PPh}_{3}$ as a function of $\omega$ (rotation of a phenyl ring about $\mathrm{P}$ $\mathrm{C}_{\mathrm{Ph}}$ bond) and $\theta$ (rotation of $\mathrm{PPh}_{3}$ about W-P bond). The dark blue areas present the lowest energy geometries (conformations). 2-D colour key right (1 a.u. $\left.=2625.5 \mathrm{~kJ} \mathrm{~mol}^{-1}\right)$.

(a)
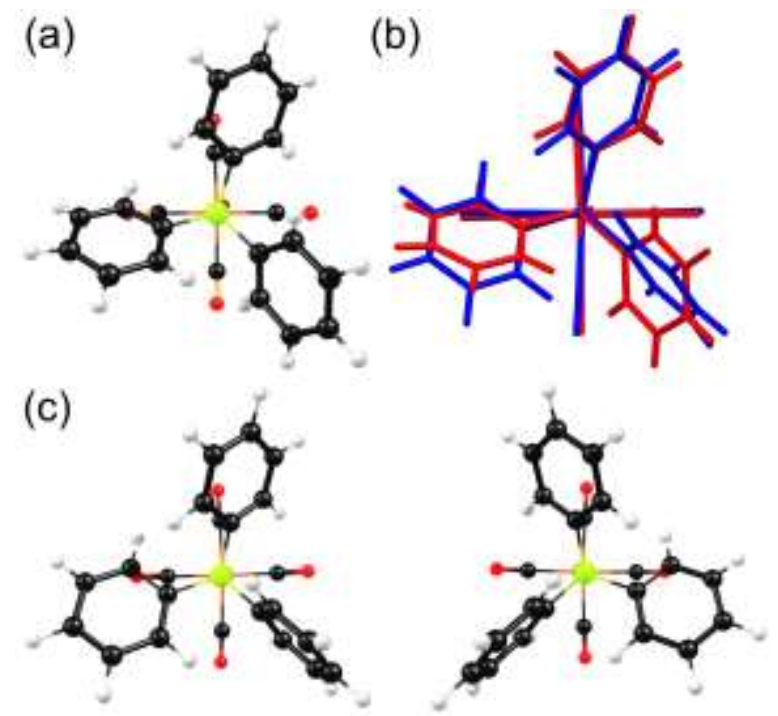

Figure 11. $\left[(\mathrm{CO})_{5}\left(\mathrm{PPh}_{3}\right) \mathrm{W}\right]$ : (a) The experimental structure (clockwise orientation of $\left.\mathrm{PPh}_{3}\right)$ (b) an overlay of experimental (red) and calculated (blue) and (c) the two DFT calculated minimum energy conformations as viewed along the $\mathrm{P}-\mathrm{W}$ axis.

The same method described above for $\left[(\mathrm{CO})_{5}\left(\mathrm{PPh}_{3}\right) \mathrm{W}\right]$, is used to determine the PES of 6trans, presented in

Figure 12. Twelve minimum energy areas were obtained, representing only four restrained geometries or two pairs of enantiomers, the geometry of which is illustrated in Figure 13. The geometries differ due to two different orientations of the carbene ligand $\mathrm{C}(\mathrm{OEt}) \mathrm{Fu}$. The orientation of the $\mathrm{P}_{-} \mathrm{C}_{i}$ bonds and the phenyl rings in the four restrained geometries are similar to the expected orientation, only ring B is slightly more tilted than expected (Figure 
13). These restrained local minimum energy geometries were re-optimized without any constraints to find the real global minimum energy geometry. Only two unique global minimum energy conformations are obtained for 6-trans, one with the OEt group of the carbene ligand pointing downwards (dihedral angle $\mathrm{P}-\mathrm{W}-\mathrm{C}_{\text {carbene }}-\mathrm{O}=177.9^{\circ}$ ) and the other with the OEt group of the carbene ligand pointing upwards (dihedral angle $\mathrm{P}-\mathrm{M}-\mathrm{C}_{\text {carbene }}-\mathrm{O}=-$ $\left.175.4^{\circ}\right)$. The orientation of $\mathrm{PPh}_{3}$ in the latter is very similar to the experimental structure, see Figure 14. During the final geometry optimization phenyl ring B rotated until it is tilted towards ring A, as observed in the experimental structure, see the overlay in Figure 14 (d). Although the reason for the difference in orientation of the phenyl rings in 6-trans from the typical experimentally observed orientation of $\mathrm{PPh}_{3}$ in related structures is still unclear, DFT did not fail to calculate the real experimental structure.
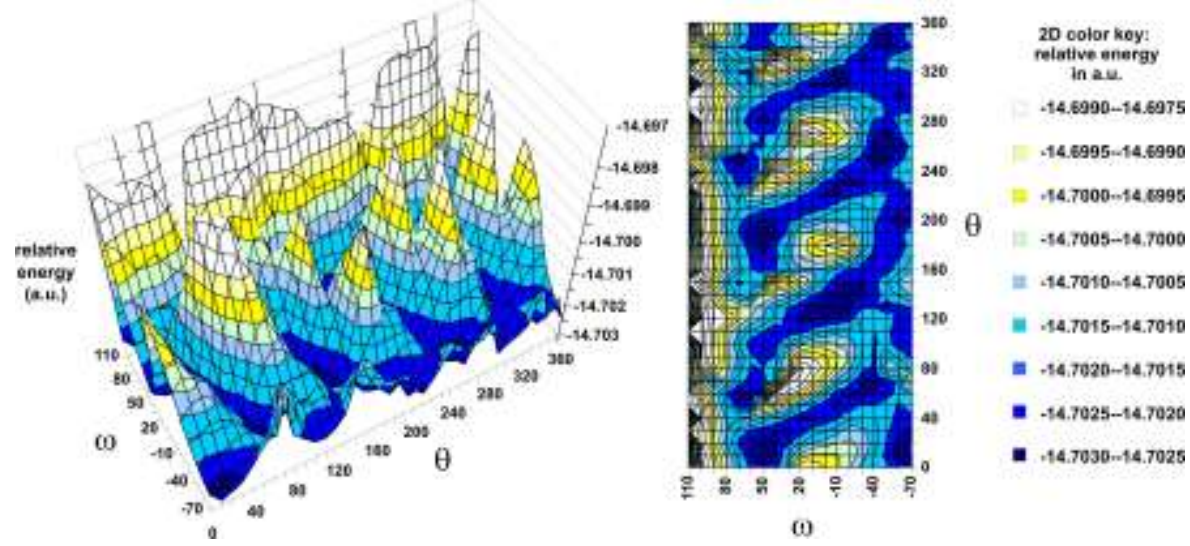

$\omega$

Figure 12: A 3-D (left) and 2-D (middle) potential energy surface (PES) of 6-trans representing the relative energy (in a.u.) of different conformations of $\mathrm{PPh}_{3}$ as a function of $\omega$ (rotation of a phenyl ring about $\mathrm{P}-\mathrm{C}_{\mathrm{Ph}}$ bond) and $\theta$ (rotation of $\mathrm{PPh}_{3}$ about W-P bond). The dark blue areas present the lowest energy geometries (conformations). 2-D colour key right $\left(1\right.$ a.u. $\left.=2625.5 \mathrm{~kJ} \mathrm{~mol}^{-1}\right)$.

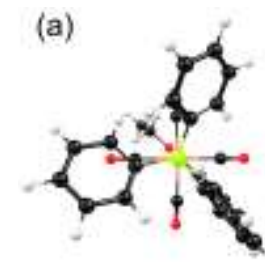

(b)

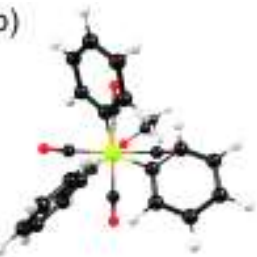

(c)

(d)
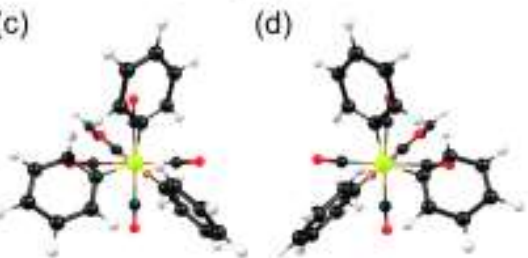

Figure 13. The four DFT calculated local minimum energy conformations of 6-trans (view along the P-W axis) obtained from the PES in 
Figure 12. In (a) and (b) the carbene ligand is orientated in such a way that the OEt group points upwards, while in (c) and (d) the furyl ring points upwards. The global minima structures are shown in Figure 14.
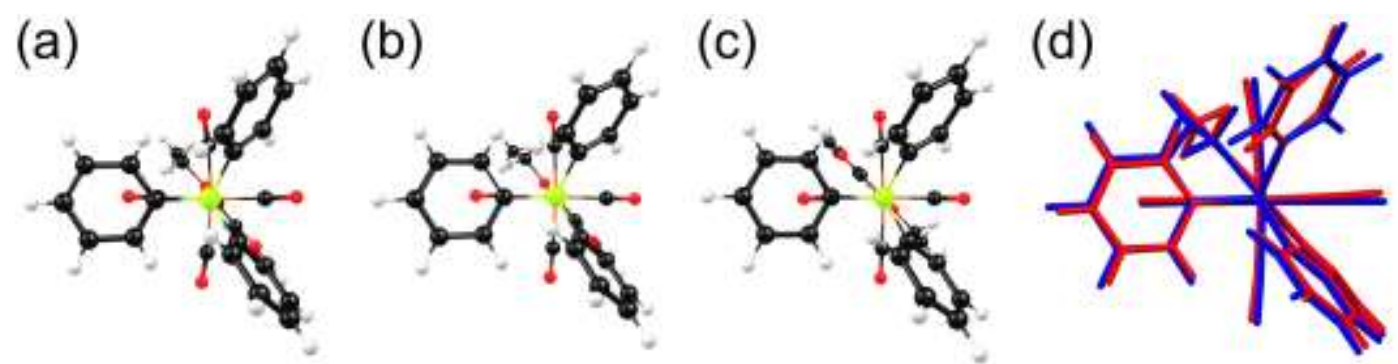

Figure 14. The experimental (a) and the two unique equi-energetic DFT calculated global minimum energy conformations (b) and (c) of 6-trans (view along the P-W axis) obtained from a full geometry optimization without any constraints. In (a) and (b) the carbene ligand is orientated in such a way that the OEt group points upwards, while in (c) the OEt group points downwards. Overlay of experimental (a) and DFT calculated global minimum energy conformations (b) is shown in (d).

\section{Conclusions}

DFT calculations, in agreement with experimental crystal structures, show that the general orientation of $\mathrm{PPh}_{3}$ in octahedral $\left[(\mathrm{CO})_{4}\left(\mathrm{PPh}_{3}\right) \mathrm{ML}\right]$ complexes involves a correlated feathering of the phenyl groups with the $\mathrm{P}-\mathrm{C}_{i}$ bond of one phenyl group orientated near parallel to the nadir plane, and the $\mathrm{C}_{m}$ of the other two phenyl groups orientated as near as possible to the nadir plane, orthogonal to the first. DFT did not fail to correctly calculate the unexpected and not generally experimentally observed orientation of $\mathrm{PPh}_{3}$ in 6-trans, $\left[(\mathrm{CO})_{4}\left(\mathrm{PPh}_{3}\right) \mathrm{W}=\mathrm{C}(\mathrm{OEt}) \mathrm{Fu}\right]$.

\section{Acknowledgements}

Financial assistance by the South African National Research Foundation and the Central Research Fund of the University of the Free State (JC) and the University of Pretoria (ML and PHvR), is gratefully acknowledged. The High Performance Computing unit at the UFS for computer time (JC).

\section{References}

[1] (a) W. Jiang, M.J. Fuertes, W.D. Wulff, Tetrahedron 56 (2000) 2183. (b) G. Frenking, N. Fröhlich, Chem. Rev. 100 (2000) 717.

[2] K.H. Dötz, Angew. Chem. Int. Ed. 23 (1984) 587.

[3] (a) M.Á. Fernández-Rodríguez, P. García-García, E. Aguilar, Chem. Commun. 46 (2010) 7670. (b) M.A. Sierra, J. Am. Chem. Soc. 123 (2001) 851.

[4] (a) D.F. Harvey, K.P. Lund, J. Am. Chem. Soc. 113 (1991) 8916. (b) J. Barluenga, F, Rodríguez, F,J. Fañanás, J. Flórez, Topics Organomet. Chem. 13 (2004) 59. (c) T. J. Katz, N. Acton, Tetrahedron Lett. 17 
(1976) 4251. (d) T.J. Katz, Fischer Metal Carbenes and Olefin Metathesis, in Handbook of Metathesis: Catalyst Development (ed R. H. Grubbs), Wiley-VCH Verlag GmbH, Weinheim, Germany (2008).

[5] (a) M.L. Clarke, J.J.R. Frew, Organometallic Chemistry; The Royal Society of Chemistry: London (2009) Vol. 35, p 19. (b) W.A. Herrmann, L.J. Goossen, G.R.J. Artus, C. Köcher, Organometallics 16 (1997) 2472.

[6] M.D. Cooke, E.O. Fischer, J. Organomet. Chem. 56 (1973) 279.

[7] (a) I. Fernández, F.P. Cossío, M.A. Sierra, Acc. Chem. Res. 44 (2011) 479. (b) A. Arrieta, F.P. Cossío, I. Fernández, M. Gomez-Gallego, B. Lecea, M.J. Mancheno, M.A. Sierra, J. Am. Chem. Soc. 122 (2000) 11509. (c) M.L. Lage, I. Fernández, M.J. Mancheño, M. Gómez-Gallego, M.A. Sierra, Chem. Eur. J. 16 (2010) 6616.

[8] (a) S. Sakaki, S. Hashimoto, G. Koga, K. Ohkubo, J. Chem. Soc. Dalton Trans. (1988) 1641. (b) B.C. Hamann, J.F. Hartwig, J. Am. Chem. Soc. 120 (1998) 7369. (c) J. Flapper, P. Wormald, M. Lutz, A.L. Spek, P.W.N.M. van Leeuwen, C.J. Elsevier, P.C.J. Kamer, Eur. J. Inorg. Chem. 31 (2008) 4968.

[9] G.H. Spies, R.J. Angelici, Organometallics 6 (1987) 1897.

[10] H. Meerwein, Org. Synth. 46 (1966) 113.

[11] J.A. Connor, E.M. Jones, J. Chem. Soc (A) 12 (1971) 1974.

[12] C. Crause, S. Lotz, Dalton Trans. 9 (2005) 1649.

[13] M. Landman, H. Görls, S. Lotz, Z. Anorg. Allg. Chem. 628 (2002) 2037.

[14] S. Aoki, T. Fujimura, E. Nakamura, J. Am. Chem. Soc. 114 (1992) 2985.

[15] M. Landman, R. Pretorius, B.E. Buitendach, P.H. van Rooyen, J. Conradie, Electrochim. Acta, Submitted.

[16] APEX2 (including SAINT and SADABS); Bruker AXS Inc., Madison, WI(2012).

[17] G.M. Sheldrick, Acta Crystallogr. A64 (2008) 112.

[18] L.J.J. Faruggia, Appl. Crystallogr. 30 (1997) 565.

[19] G. te Velde, F. M Bickelhaupt, E. J. Baerends, C. Fonseca Guerra, S. J. A. van Gisbergen, J. G. Snijders and T. Ziegler, J. Comput. Chem. 22 (2001) 931.

[20] C. Fonseca Guerra, J. G. Snijders, G. te Velde and E. J. Baerends, Theor. Chem. Acc. 99 (1998) 391.

[21] ADF2012.01, SCM, Theoretical Chemistry, Vrije Universiteit, Amsterdam, The Netherlands.

[22] J. P. Perdew, J. A. Chevary, S. H. Vosko, K. A. Jackson, M. R. Pederson, D. J. Singh and C. Fiolhais, Phys. Rev. B 46 (1992) 6671. Erratum: J. P. Perdew, J. A. Chevary, S. H. Vosko, K. A. Jackson, M. R. Perderson, D. J. Singh, C. Fiolhais, Phys. Rev. B 48 (1993) 4978.

[23] D. A. Skoog, D. M. West, F. J. Holler, Fundamentals of Analytical Chemistry, 7th edn., Brooks/Cole, Australia, 1996, p. 28.

[24] Cambridge Structural Database (CSD), Version 5.34, may 2013 update, CSD reference codes: EWEYIO, FIPNIB, GOFXOP, JELGEN, JELGIR, MEJLAO, QESYOC, QESYUI, WEXMUI, ZAFWEI.

[25] E.O. Fischer, R. Aumann, Chem. Ber. 102 (1969) 1495.

[26] R. Stumpf, M. Jäger, H. Fischer, Organometallics 20 (2001) 4040.

[27] K.H. Dötz, H. Larbig, K. Harms, Chem. Ber. 125 (1992) 2143.

[28] C.A. Caputo, M.C. Jennings, H.M. Tuononen, N.D. Jones, Organometallics 28 (2009) 990.

[29] B. Weberndörfer, H. Werner, J. Chem. Soc. Dalton Trans. (2002) 1479.

[30] H.C. Jahr, M. Nieger, K.H. Dötz, Chem. Eur. J. 11 (2005) 5333.

[31] E.O. Fischer, H. Fischer, H. Werner, Angew. Chem. Int. Ed. 11 (1972) 644.

[32] (a) M. Landman, H. Görls, S. Lotz, J. Organomet. Chem. 617 (2001) 280. (b) S. Lotz, M. Landman, H. Görls, C. Crause, H. Nienaber, A.J. Olivier, Z. Naturforsch. B: Chem. Sci. 62 (2007) 419.

[33] (a) L. Meca, D. Dvořák, J. Ludvík, I. Císařová, P. Štěpnička, Organometallics 23 (2004) 2541. (b) R.

Streubel, S. Priemer, J. Jeske, P.G. Jones, J. Organomet. Chem. 617 (2001) 423.

[34] P.G.Jones, F.Ruthe, Private Communication to CCDC (2007).

[35] À. Pintèr, G. Haberhauer, I. Hyla-Kryspin, S. Grimme, Chem. Commun. (2007) 3711.

[36] (a) K. Mislow, Acc. Chem. Res. 9 (1976) 26. (b) C. Bolm, K.B. Sharpless, Tetrahedron Lett. 29 (1988) 5101.

[37] J. F. Costello, S. G. Davies, J. Chem. Soc. Perkin Trans. 2 (1998) 1683.

[38] (a) H. Brunner, B. Hammer, C. Kruger, K. Angermund, I. Bernal, Organometallics 4 (1985) 1063. (b) J.J. Daly, J. Chem. Soc. (1964) 3799. (c) J. Bruckmann, C. Kruger, F. Lutz, Z. Naturforsch. B50 (1995) 351.

[39] (a) J. Conradie, Dalton Trans. 41 (2012) 10633. (b) N.F. Stuurman, A. Muller, J. Conradie, Inorg. Chim. Acta 395 (2013) 237. (c) N.F. Stuurman, A. Muller, J. Conradie, Trans. Met. Chem. 38 (2013) 429.

[40] J. F. Costello, S. G. Davies, D. McNally, Perkin Trans. 2 (1999) 465.

[41] Cambridge Structural Database (CSD), Version 5.34, may 2013 update, CSD reference codes: QESYOC, JELGEN, JELGIR, WEXMUI, QESYUI-1, QESYUI-2, ZAFWEI, EWEYIO, GOFXOP, MEJLAO.

[42] Cambridge Structural Database (CSD), Version 5.34, May 2013 update, CSD reference codes: HEWYOX, LABBIZ, NITMIN, CNETPC, NALVUR, CNETPC01, PCTPCR10, PCTPCR11, RIBWAA, OCUHID01, 
OCUHID, REXSES, TAHTED, TAHTIH, XATCEA, DAFNAZ, DAFNED, BEKHII, CADKAT, CESRIB, PORRUJ. 